\title{
COP26 Futures We Want - Kenya Country Profile
}

The purpose of this draft country profile was to provide an evidence base to inform the production of Net Zero Future visions. A consolidated version of the material contained here was used as a stimulus for in-country workshops and creative translational approaches that will develop a plausible vision for each country. This document provides a selection of relevant evidence for the sectors and themes identified through the scoping exercise.

\section{Part A: Executive Summary}

This country profile for Kenya has been developed with the input from in-country academic experts, including Prof John M. Wesonga (Jomo Kenyatta University of Agriculture and Technology) and Dr Linda Nkatha Gichuyia (University of Nairobi), in the context of the BEIS COP26 Futures We Want project. It provides a review of the available evidence on the risks, solutions and opportunities for Brazil and Brazilian society to contribute towards a global transition to a net zero future that is inclusive, resilient and desirable by all.

With a growing Human Development Index, a national Big Four Agenda' focused on inclusive economic growth and improved access to health and social amenities, as well as a National Climate Change Strategy, Kenya has begun extensive work to coordinate action to climate-proof its economy and build climate resilience.

The impact of climate change is already being experienced in key sectors of its economy; from impacts on agriculture, to tourism, to the livelihoods of pastoral and coastal communities, to the lifespan of infrastructure, to mention but a few. While these threats can compromise the country's export-import balance, debt performance, health outcomes, and its development trajectory, there is also the potential for a climate-resilient pathway that enables development-compatible growth in the country.

A development-compatible pathway may be catalysed by reducing emissions in economic value chains (e.g., in transport, agriculture, industry standards, and financial services) as this will allow for the proper valuation of ecological stewardship. To 
actualise this pathway, multiple local scenarios that recognise the linkages between rural and urban landscapes, informal and formal settlements, as well as the varying social, spatial, and climatic conditions, are needed.

Additionally, investments and innovation to deliver a net-zero pathway need to be linked with efforts to address the infrastructure gap and economically empower marginalised populations including young people, remote populations, and informal settlements. Institutional strengthening informed by community-oriented data and evidence-informed frameworks adapted to the local context will be necessary to maintain momentum along this trajectory. Efforts to create inclusive markets and mobilise capital through innovative financing tools and appropriate regulatory frameworks are needed.

This brief provides key examples of ongoing transformations across multiple sectors of the Kenyan economy and highlights opportunities to strengthen and improve the effectiveness of these initiatives. With due consideration given to rights, inclusion and local relevance, the net-zero transition could yield benefits across sectors, from agriculture, to health, to social and physical infrastructure, and the economy at large.

\section{Part B: Expert Committee Inputs}

\section{Country Context}

\section{1.a Economic Context}

\section{1.a.i Sectors that contribute most to the country's GDP}

Kenya is one of the largest economies in Eastern Africa. It has an estimated population of 46.6 million, a land area of $580,367 \mathrm{~km}^{2}$, and contributes about $40 \%$ of the East African Commission's regional Gross Domestic Product (GDP)ii. By Gross Value Added (GVA) to the Kenyan Gross Domestic Product (US\$76.367 billion as of 2017iii), agriculture leads the Kenyan economy, contributing about $37.7 \%$ of total GVA. It is followed by manufacturing $(8.6 \%)$, wholesale trade $(8.2 \%)$, the financial sector $(8.1 \%)$, the transportation sector $(8 \%)$, real estate $(7.6 \%)$ and construction $(6 \%)^{\text {iv }}$.

A geographic breakdown of the size and structure of economies at the county level, known as the Gross County Product (GCP), demonstrates that counties like Nairobi, 
Nakuru, Kiambu, Mombasa and Nyandarua make the largest contributions to Kenya's GDP. These counties also have strong activities in several sectors listed above which sustain the Kenyan economy. Nairobi alone contributes over half of the total national GVA from manufacturing, and almost half of the total national GVA from wholesale trade. Nakuru county makes the highest county agricultural contribution to the GDP (with a GVA of 303349 [Ksh million] from agriculture) ${ }^{\mathrm{v}}$.

Economic priorities in Kenya reflect the growth sectors listed above, as well as the current government's Big Four agenda, which has a focus on the provision of universal healthcare, improving access to food and nutrition, growing the manufacturing sector's share of the economy to $15 \%$ and the creation of affordable housing vi. However, significant limitations in the form of infrastructure, energy and governance gaps exist, as well the ongoing risks from the reliance of the agricultural sector on rainfall, whose patterns are already affected by climate change. Heavy reliance on the importation of capital to finance infrastructure gaps particularly in transport and energy have placed the economy in a deficit, despite surpluses in the inflow of portfolio investments.

Additionally, Kenya's informal sector accounts for about $34 \%$ of its GDP and over $77 \%$ of employment in the countryvii. The informal sector is typically understood as parts of the economy that are not governed by formal arrangements such as the reporting of income or declaration of taxes, in law or practice viiiix. An estimated $60 \%$ of the informally employed are young people between the ages of 18 and 35 years oldx.

\section{1.a.ii Sectors that represent growth areas for the country economically (in absolute terms, but also as a proportion of GDP)}

In 2014, Kenya was classified as a lower-middle income country due to a steadily rising GDP from 2012 ${ }^{\mathrm{xi}}$. This economic performance was attributed to agriculture which remains a mainstay of the economy. From 2012 to 2017, the Kenyan economy had an estimated growth rate of 5.5\% annually, which exceeded its average growth of $4.7 \%$ from 2008 to 2012 . The growth in the Kenyan economy was attributed to growth in the services sector particularly transport, real estate, wholesale, retail trade, tourism and the financial sector. Together, these sectors contributed about half of the Kenyan GDP. Agriculture alone accounted for $37.7 \%$ of the GDP in 2017 , significantly higher than its share of $29.1 \%$ in 2012 . In this same period, declines were evident in its diversified manufacturing sector, whose share of the GDP contributions dropped from 
$13.1 \%$ to $8.6 \%$. Favourable factors for the growth in agriculture have included consistent production of tea and investments in horticulture ${ }^{\text {xixiii. }}$. In the manufacturing sector, recent declines have been attributed to increased costs of production and reduced availability of raw materials which make competition with imported goods stiff.

\section{1.a.iii. Major trade-flows (goods and services) in and out of the country today}

Kenya accounts for about $0.03 \%$ of exports of goods, and $0.09 \%$ of goods imports globallyxiv. Agriculture accounts for most Kenyan exports particularly in the form of flowers, tea and coffee (about $60.4 \%$ of total exports). Exports from Kenya appear to be declining. Its international trade in goods and services experienced a steep decline from $61.7 \%$ in 2011 to $37.3 \%$ in 2017 . While the bulk of exports from Kenya are to destinations within Africa, new trends are emerging. In 2011, 48.3\% of Kenyan exports were pan-African, as against $37.7 \%$ in 2016. In 2011, 26.8\% of Kenyan exports were to partners in the East African Community (EAC) and this figure dropped to $19.3 \%$ in 2016. In 2017, both figures declined. Notably, $10.8 \%$ of Kenya exports were to Pakistan in 2017. Kenya is also a net exporter of services due to a growth in travel and tourism. The services sector accounted for an estimated 18.5\% of GDP in 2017.

On the other hand, imports to Kenya appear to be increasing from partners in Africa and Asia. Total imports from African partners constitutes $11.6 \%$ of Kenya's imports, while imports from the EAC are about 3.5\%. Imports from the Asian region are experiencing significant growth and currently constitute $47.5 \%$ of Kenya's imports. China is the top source of Kenya's imports, accounting for $22.6 \%$ of total imports to the country. Other imports come from the Middle East, India and Europe. Kenya also relies heavily on the importation of Foreign-Direct Investments (FDI) via long-term forms of debt, equity and investment shares constituting about half of all FDI to the EAC. These investments go primarily to its tourism, telecommunication and agroprocessing sectors ${ }^{\mathrm{xv}}$. Significant contributors to foreign-direct investments include South Africa, China, the United States of America, and the United Kingdom.

In 2019, Kenya ranked $63^{\text {rd }}$ of the economies in the world in terms of GDP (current US\$), $107^{\text {th }}$ in total exports, $80^{\text {th }}$ in total imports, $146^{\text {th }}$ in terms of GDP per capita (current US\$) and the $96^{\text {th }}$ most complex economy according to the Economic Complexity Index $(\mathrm{ECl})$. The top exports of Kenya ${ }^{\mathrm{xvi}}$ are tea $(\$ 1.13 \mathrm{~B})$, cut flowers 
$(\$ 616 \mathrm{M})$, refined petroleum $(\$ 404 \mathrm{M})$, Coffee $(\$ 224 \mathrm{M})$, and titanium ore $(\$ 143 \mathrm{M})$, with exports mostly going to Uganda $(\$ 619 \mathrm{M})$, the United States $(\$ 546 \mathrm{M})$, Netherlands $(\$ 487 \mathrm{M})$, Pakistan $(\$ 440 \mathrm{M})$, and the United Kingdom $(\$ 387 \mathrm{M})$. The top imports of Kenya are refined petroleum $(\$ 3.07 \mathrm{~B})$, cars $(\$ 522 \mathrm{M})$, packaged medicaments $(\$ 471 \mathrm{M})$, wheat $(\$ 439 \mathrm{M})$, and hot-rolled Iron $(\$ 413 \mathrm{M})$, with imports mostly coming from China (\$4.48B), United Arab Emirates (\$1.83B), India (\$1.82B), Saudi Arabia (\$1.28B), and Japan (\$910M).

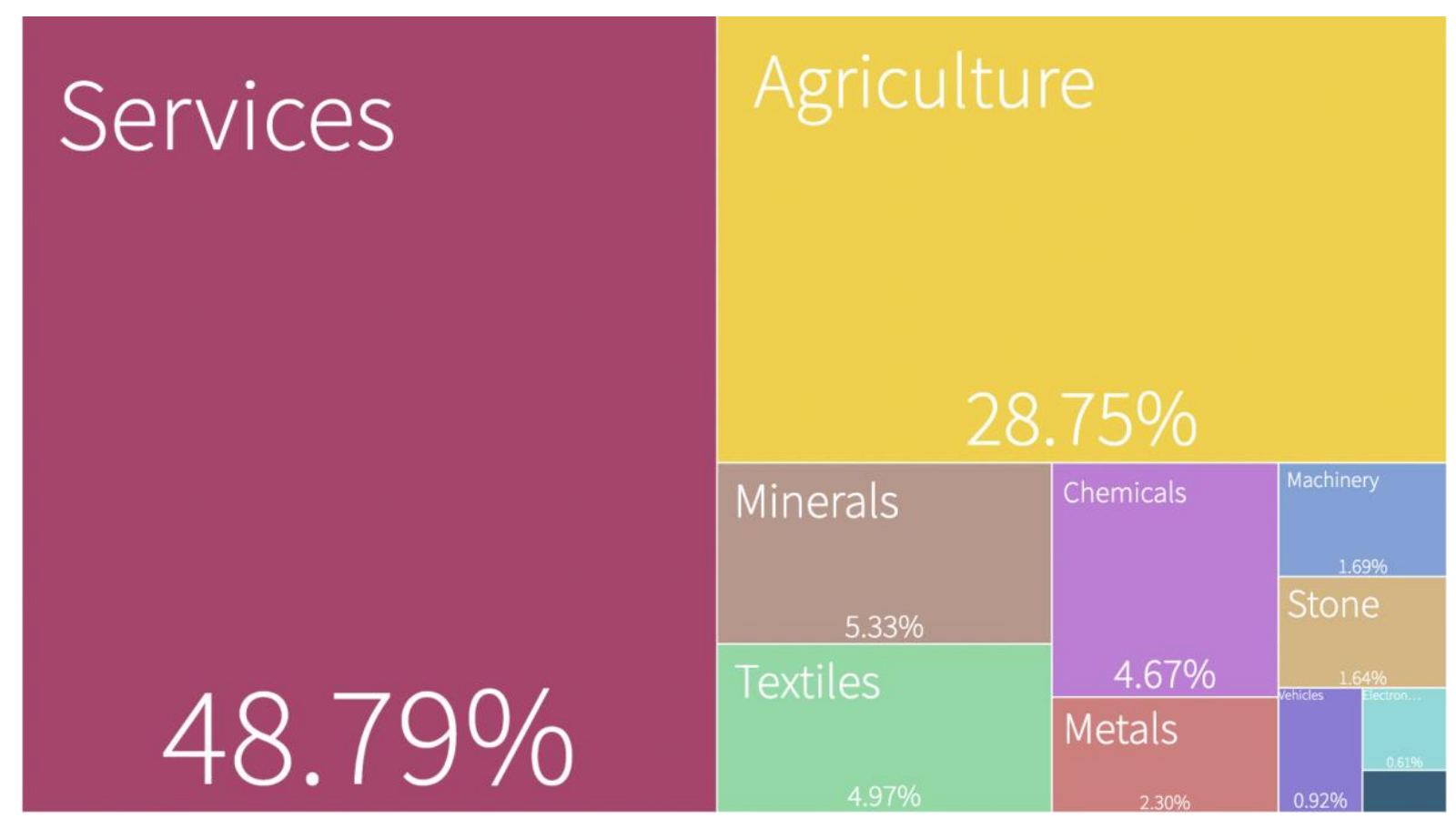

Figure 1: Kenya's exports in 2019xvii

\section{1.b Development Context}

\section{1.b.i What are the key development indices for this country?}

As of 2018 , Kenya ranks 143 rd out of 189 countries with a Human Development Index score of 0.601 , representing a $24.7 \%$ increase from the value of 0.482 in $1990^{\text {xviiixix. It }}$ is marked by high income inequality, with its top income quintile incurring expenditures that are approximately 700 times that of its bottom quintile. $42.8 \%$ of its population and $80 \%$ of the population in its north-eastern counties live below the international poverty lines of USD 1.90 a day. $12 \%$ of the population is estimated to live in poverty. About 
$91 \%$ of its population is enrolled in primary schools, and about $51 \%$ in secondary schools. Prevalence of moderate or severe food insecurity stands at $56.5 \%$, while the prevalence of severe food insecurity was $19.1 \%$ as of $2016^{x x}$. The brunt of food insecurity in Kenya is borne by populations in arid and semi-arid lands.

\section{Number of severely food insecure people (million) (3-year average)}

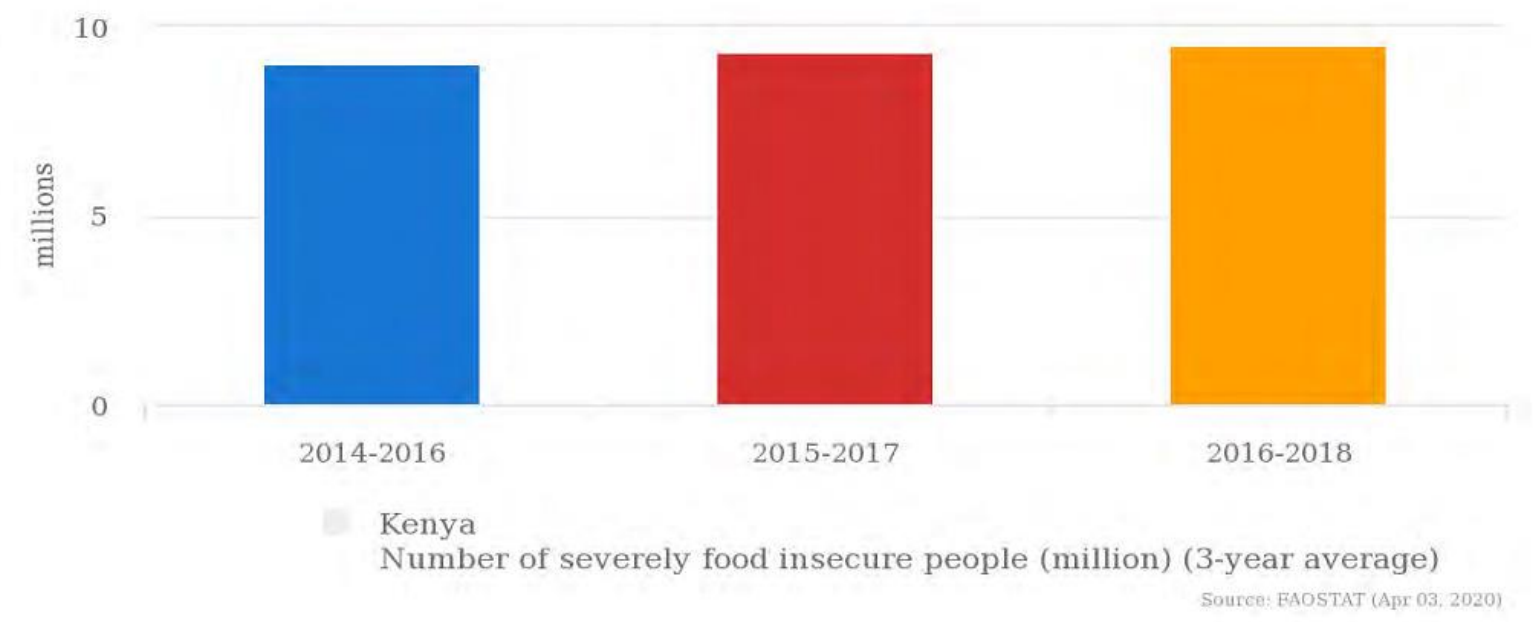

Figure 2: Number of severely food-insecure people (million) (3-year average).

Source: FAOSTAT ${ }^{\times 1}(04 / 03 / 2020)$

Kenya scored 54.14 points out of 100 and ranked 95th out of 140 on the 2019 Global Competitiveness Report (published by the World Economic Forum)xxii. Kenya had a Gross National Income (GNI) of 1750 in 2019, and World Bank data suggests that the GNI of Kenya has been rising steeply since the early $2000 \mathrm{~s}^{x x i i i}$. The proportion of Kenyans living below the international poverty line (US $\$ 1.90$ per day in 2011 PPP) has reduced from $43.6 \%$ in $2005 / 06$ to $35.6 \%$ in $2015 / 16^{\text {xxiv }}$. Kenya has a youthful rural population, according to the 2019 census by the Kenya National Bureau of Statistics $(\mathrm{KNBS})^{\mathrm{xxv}}$. Additionally, the Sustainable Development Goals Report indicates that Kenya has made some progress toward its SDG targets for reducing emissions from fuel, cement production and imports - although it has recorded decreasing progress toward maintaining biodiversity on land and water ${ }^{x \times v i}$. General demographics show that there are 35.7 million Kenyans $(75.1 \%)$ below 35 years. There are 24.014 million females, constituting $50.4 \%$ of the population. The life expectancy at birth as of 2019 was $66.669 \times x$ vii. 


\section{1.b.ii What are the priorities and barriers to enabling the country's sustainable, inclusive and resilient growth?}

Kenya is implementing key projects in the priority areas of housing, health, food security and manufacturing under its "the Big Four Agenda"xxviii, several of which are compatible with sustainable development and will also support inclusion and resilience. Some of these flagship projects have thematic priorities in climate change and risk management. They include the government's goal to increase the number and distribution of green jobs, reduce gross greenhouse gas emissions per year, integrate climate change and disaster risk reduction via GIS-based spatial plans and legislative frameworks for disaster risk management at the county level, and reduce the number of people missing, killed and affected by disaster on a national levelexix.

Capital continues to be concentrated largely in urban centres which drive a significant amount of the GDP growth. However, consistent, sustainable, inclusive and resilient valuing of natural resource endowments in the countryside needs to become an increasing priority. These can contribute to increased growth through valuing their ecosystem assets and informal expertise, and can also create localized solutions to climate change, food security and biodiversity. ${ }^{\mathrm{xx}}$

Risks, opportunities, and the distribution of the dividends from growth areas of the economy such as the services sector and agricultural sector will need to be reviewed to ensure that they are future-proof. For example, the agricultural sector which largely upholds the economy currently relies significantly on rainfall patterns and will need to be made more resilient to climate-induced changes in rainfall patterns. Services, trade, and tourism will all be impacted by changing landscapes and this will lead to impacts on biodiversity, food production, disasters, and conflict. Additionally, there is a need to build on local expertise in indigenous communities in driving the sustainable economy and accruing dividends to a greater share of the country's economy to close the significant levels of educational, economic, spatial, and social inequalities. Initiatives such as Kenya Climate Atlas ${ }^{\mathrm{xx} i}$ that seeks to provide localised climate change scenarios or the Kenya Agricultural Observatory Platform that provides localised 
weather information should be embraced, supported and upscaled to provide critical evidence for policy-making and practice.

To ensure sustainable, inclusive and resilient growth in Kenya, there is a need to strengthen its contributions to the global economy to skew the balance between its imports and exports toward an export surplus. It is also vital for the FDI investment inflows to be reviewed and structured in ways that are conducive for its long-term economic wellbeing, particularly given its high levels of debt and its need for continued infrastructural development.

\section{1.c Development-compatible greenhouse gas emissions (GHGe)}

\section{1.c.i Country's current GHG emissions profile}

Kenya makes minimal contributions to global greenhouse gas (GHG) emissions, estimated at around $0.04 \%$ of global annual generation ${ }^{\times \times x i i}$. Its contributions are placed at less than $1 \%$ of the total global emissions, ${ }^{\text {xxxiii }}$ and were estimated to be $0.13 \%$ of global GHG emissions in 2013 ${ }^{x x x i v}$. However, Kenya's global GHG emissions are expected to rise from 73 million tonnes of carbon dioxide equivalent in 2010 to 143 million tonnes in 2030 under a business-as-usual scenario. ${ }^{\mathrm{x} \times \mathrm{v}}$ 


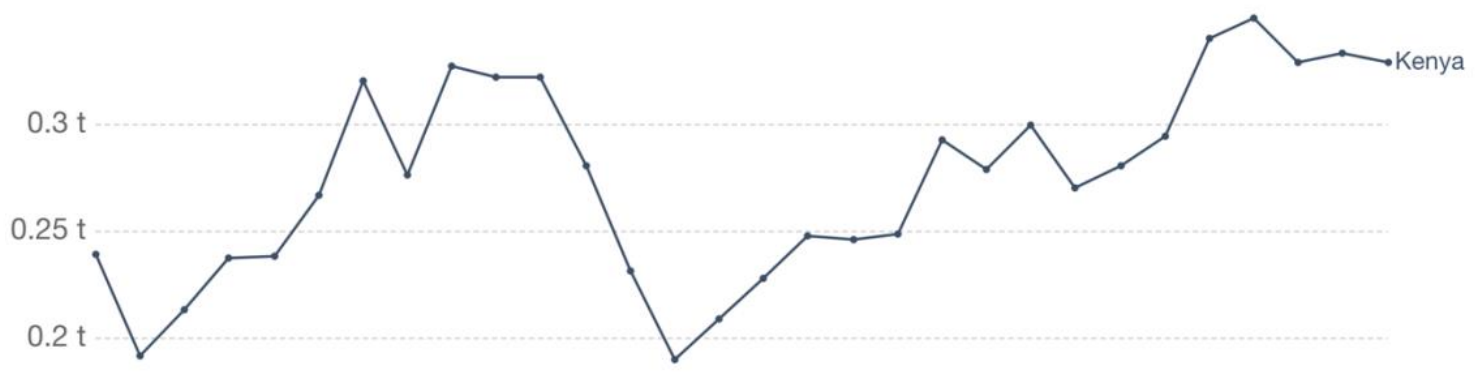

$0.15 \mathrm{t}$

$0.1 \mathrm{t}$

$0.05 \mathrm{t}$

$0 \mathrm{t}$

1990

1995

2000

2005

2010

2015

2019

Source: Our World in Data based on the Global Carbon Project; Gapminder \& UN

Note: $\mathrm{CO}_{2}$ emissions are measured on a production basis, meaning they do not correct for emissions embedded in traded goods.

OurWorldlnData.org/co2-and-other-greenhouse-gas-emissions/ • CC BY

Figure 3: Per Capita CO2 emissions for Kenya from the burning of fossil fuels and cement production (land use change not included) (1990-20199). Source: Our World in Dataxxvi.

\section{1.c.ii Sector-specific GHG emissions from the sectors which are key for development in this country}

Going by growth, agriculture is the highest GHG-emitting sector of the Kenyan economy, contributing about $62.8 \%$ of total national-levels emissions, with energy, industrial activities and waste following at $31.2 \%, 4.6 \%$ and $1.4 \%$ respectively. It is expected that the GHG emissions from the Kenyan agricultural sector will rise from its value of $20 \mathrm{MtCO}_{2} \mathrm{e}$ in 2010 to $27 \mathrm{MtCO}_{2} \mathrm{e}$ in 2030 due to increases in land use changes and livestock methane emissions ${ }^{\times x x v i i}$. Currently, these two factors contribute to about $30 \%$ of national emissions and $90 \%$ of the agricultural emissions. Being rainfed, the agricultural sector is one for which climate change poses a key risk in the form of changes in temperature, precipitation and the prevalence of extreme weather, all of which are associated with climate change. There could also be the emergence of new pests as has been experienced with locusts in the recent past. Between 2019 and 2021, large locust infestations had a significant social and economic impact on Kenyan 
agriculture, with climate change playing a key role in creating the conditions for the breeding, development and migration of the locusts ${ }^{\mathrm{xx} x \mathrm{iii}}$. The agricultural sector itself also poses risks due to land degradation and deforestation ${ }^{\mathrm{xxxix}}$.

A prominent growth sector to Kenya's economy is the built environment and construction sector. Besides being a key contributor to the GDP, the sector has other significance in the country by way of 1 ) its employment volume, 2 ) its share of services and consultancies 3 ) its impact on health and wellbeing, 4) its high visibility as a process and product of development 5) and its multiplier effect across many other sectors in Gross National Product among others. There has been a construction boom in the last 10 years following the promulgation of a new constitution that introduced a devolved government system ${ }^{\times 1}$. Because of the broad suggestion that the visibility of building and infrastructure projects is a sign of development, each of the 47 counties has undergone a relatively high construction boom in the last 10 years as they establish themselves as semi-independent county governments. Following this increase in construction, preliminary studies have noted some buildings contributing as high as $19.26 \mathrm{t} / \mathrm{m}^{2}$ of Global Warming Potential per building footprint area, and with those most passively designed and built contributing to $1 \mathrm{t} / \mathrm{m}^{2}$ of Global Warming Potential per building footprint area ${ }^{x i}$. 


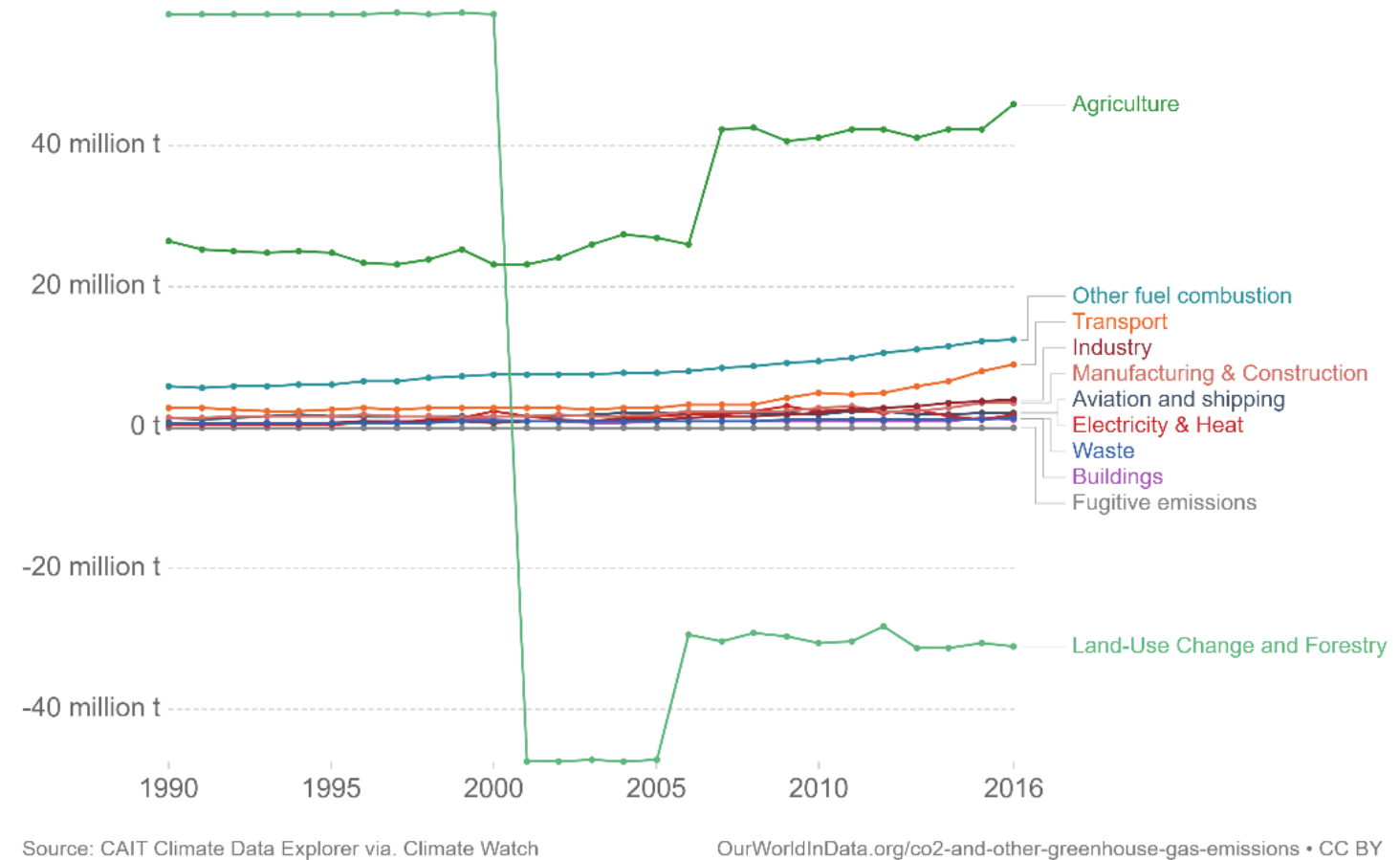

Figure 4: GHG emissions by sector for Kenya, 1990-2016 (N.b. land use change data from CAIT may not accurately reflect GHG emissions; a query has been lodged with WorldlnData). Source: Our World in Dataxlii.

\section{Physical climate change - risks, adaptation, and opportunities}

\section{2.a Physical climate risk profile}

\section{2.a.i Physical climate risks that the country is already facing}

Climate change ${ }^{\text {xliii }}$ is associated with increased variability in the frequency and intensity of rainfall events. There are projected rainfall increases from March to May, typically characterised by the 'long rains' as well as the period of the 'short rains' from October to December, which often extends into what would usually be the hot and dry months of January to February ${ }^{x l i v}$. Some studies ${ }^{x / v}$ have tracked the weather variables that influence human health and wellbeing, including thermal comfort and air quality. In the case of Nairobi's tropical upland climate for instance, studies have observed a steady rise in average dry bulb temperature and average diffuse radiation, and a steady decline in relative humidity, wind speed and atmospheric pressure. In various parts of the country, the increased intensity of rainfall is associated with severe flooding in 
recent times that has led to displacement of people and disruption of livelihoods ${ }^{\text {xlvi. }}$. For example, in 2020 severe flooding damaged crop land and led to harvest loss in many parts of central and western Kenya ${ }^{x / v i i}$. The Red Cross stated that the flooding displaced some 40,000 Kenyans. xlviii. Additionally, across all RCP scenarios, temperatures in Kenya are projected to continue rising by $1.7^{\circ} \mathrm{C}$ by the middle of the $21^{\text {st }}$ century, and by approximately $3.5^{\circ} \mathrm{C}$ at its end. This will be associated with an increase in the number of hot days and nights, from $19 \%-45 \%$ of days being hot days by mid-century, $45 \%-75 \%$ of hot nights by mid-century and $64 \%-93 \%$ of hot nights by the end of century.

$(\text { Fig. 5) })^{\text {xix }}$.

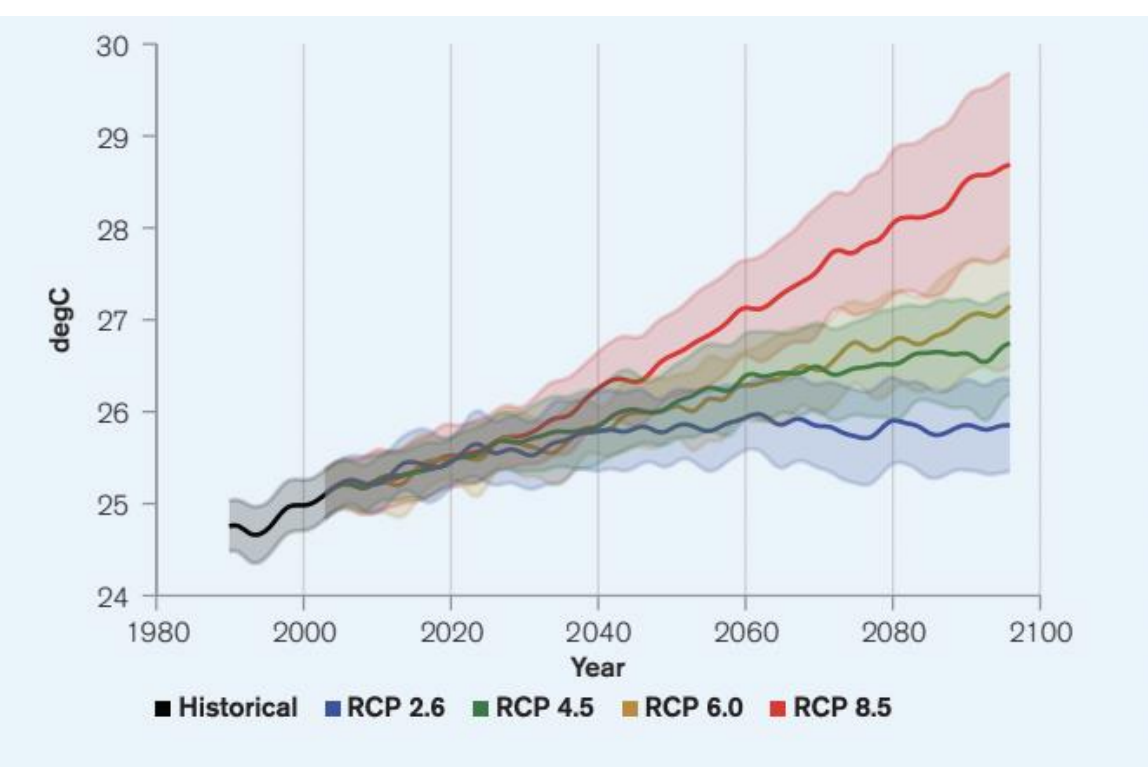

Figure 5: Projected temperature increase in Kenya across multiple RCP scenarios from 1986-2099

\section{2.a.ii How these risks are likely to change by 2050 due to climate change}

Prevalent trends in the climate risk profile suggest that certain risks may be anticipated in Kenya over time. One of these is rising temperatures. Kenya has recorded rising temperatures over recent decades, with record increases in night and daytime temperatures since the $1960 \mathrm{~s}$. The annual mean increase is estimated to be $1{ }^{\circ} \mathrm{C}$ with an average rate of $0.21^{\circ} \mathrm{C}$ per decade since $1960^{\mathrm{li}}$. Another is the impact of climate change on rainfall, with the frequency and intensity of heavy precipitation events projected to rise across Africa with additional global warminglii. Additionally, climate 
change is impacting forest cover, which has dropped from 6.2\% (3,669,768 ha) in 2002 to $5.9 \%(3,462,536 \mathrm{ha})$ in 2018 .

Another concerning trend is the rise of sea levels on Kenyan coastlines which will have an impact on the availability and safety of beaches which contribute to tourism and biodiversity, as well as on human populations due to flooding and changing disease profiles. The coastal city of Mombasa already suffers from extreme climatic events, including flooding and droughts ${ }^{\text {iiiliv. }}$. There is also a projected increase of average tropical cyclone wind speeds and associated heavy precipitation, due to a projected increase in the proportion of category 4-5 tropical cyclones. ${ }^{. v}$

On average, humans spend approximately $80 \%$ of their time indoors, ${ }^{\text {,vi }}$ and therefore another important risk to consider, is indoor overheating. In Nairobi for instance, office building occupants have an $88 \%$ chance of being overheated, by an average of $3.4^{\circ} \mathrm{C}$ above their thermal comfort thresholds. Their level of discomfort is likely to go up to $5.5^{\circ} \mathrm{C}$ above their comfort threshold, with a $95 \%$ chance of being overheated by 2080 . Ivii $^{\text {In }}$

\section{2.a.iii What additional long term climate risks might be incurred before 2100 ?}

The key risks above constitute major trends to be anticipated as a result of climate change related impacts in Kenya. However, longer-term risks will be influenced by social, demographic and spatial trends in Kenya. These are discussed in more detail below.

2.a.iv How might different physical, sociological and economic risks and vulnerabilities interact? (correlated and cascading risks, multiple interacting risks, and interconnectivity between these different physical climate risks)

There are multiple interactions and vulnerabilities that will magnify the impact of climate change on Kenya's population. Changes in forest cover are already having an impact on water catchment in Kenya's water towers, which rural and urban communities rely on for water consumption ${ }^{\text {viii. }}$. Changes in precipitation and associated runoff will have an impact on water scarcity, which is already a challenge in many parts of Kenya. Kenya is already known as a water-scarce country given the low supply of 
renewable freshwater $(<1000 \mathrm{~m} 3 / \text { capita/year })^{\text {lix }}$. This will have an impact on agropastoralist and pastoralist communities who travel to find pasture and water for the cattle that they herd. As rangelands recede, this also impacts the lifestyles and the livelihoods of these communities, thereby worsening inequalities, altering previously established nomadic patterns, and potentially leading to tensions between them and recipient communities.

Kenya's coastal belt is rich in biodiversity, being host to a range of fish, coral reefs, and mangrove forests. However, it is also one of the most vulnerable to increases in sea levels globally'x. The submergence of its land mass due to sea-level rise is an ongoing threat that will also create socioeconomic challenges. This will spur changes in fish populations via alterations in their spawning periods, the likelihood of survival of their larvae, as well as the size and life cycle of the fish population ${ }^{\mid x i}$. Fisheries form a vital part of Kenya's economic and nutritional security. A further reduction in fish stocks due to the impact of climate change would compound existing inequalities ${ }^{\mid x i i}$.

Changes in precipitation and temperatures will also affect health outcomes for the population, through the increased? spread of infectious diseases such as malaria, yellow fever, Rift Valley Fever, sleeping sickness, tuberculosis, Lyme disease, cholera, and Ebola. Increases in flooding ${ }^{\text {Ixiilxiv }}$, especially in coastal communities can raise the risk profile of diseases such as bilharzia, cholera, typhoid and amebiasis to epidemic proportions. Increased ocean temperatures and ocean acidification will lead to the increased loss and bleaching of coral reefs ${ }^{\mid \mathrm{xv}}$. Additionally, increased encroachment of human populations into animal habitats due to climate-related changes in ecological resources can increase the frequency of pandemics ${ }^{1 \times v i}$.

In addition to possible increases in pandemics, as populations experience displacement from areas prone to climate disaster, this can increase conflicts between pastoral and local populations, as well as population and wildlife that will be displaced from their habitats. Lions are currently being pushed away from their habitats, closer to human settlements as they seek new vegetation and waterholes'xvii. Meanwhile pastoral communities are starting to encroach into game parks in Kenya as they seek water and pasture for their communities. For example, in 2017, droughts in northern Kenya led pastoralists to move their cattle south into the county of Laikipia to find 
adequate grazing land, resulting in violence between pastoralists and cattle ranchers ${ }^{\text {xviii }}$. This encroachment of pastoralists is a result of both environmental factors and historical land injustices, and climate change will likely compound such existing injustices in future.

Temperature projections for East Africa indicate considerable warming under RCP8.5 where average warming across all models is approximately $4^{\circ} \mathrm{C}$ by the end of the century. Eastern Africa is projected to lose more than $80 \%$ of its glaciers by 2100 under RCP8.5. ${ }^{\text {Ixix }}$ Increasing temperatures will disrupt marine ecosystems, coastal rainforests and snow-capped mountains such as Mt Kenya, where glaciers have already reduced substantially, thus reducing water supply for downstream communities as well as their attractiveness for tourism ${ }^{\mathrm{lxx}}$. It is estimated that some of the popular beaches in Kenya may eventually disappear due to sea level rise. Hotels based on the coast are already creating sea walls in response to stronger sea tides. Additional impacts which are already being experienced and are expected to worsen include the bleaching of coral reefs, and the disruption of the migration of animals such as the wildebeest of the Mara River due to its reduced flow ${ }^{\mid x \times i}$.

Furthermore, regions such as northern Kenya are prone to drought, while coastal areas are prone to rising sea levels. As populations move away from these high-risk areas, they are likely to seek opportunities in urban areas. This will create increased infrastructural, natural resource, governance and social pressure on communities. It will also increase the burden on the already strained public health infrastructure, while reducing economic productivity. Increased pressure will also be placed on rapidly urbanising regions already marked by high inequality and low resource provision.

Finally, climate risks are interacting with desertification and environmental degradation in the form of grazing, logging, illegal encroachment into certain habitats and changing the proportion of arable, semi-arid and arid land (ASAL) in Kenya. This altered composition of land mass typology is significant given that only $11 \%$ of Kenya's landmass is currently arable via rainfed agriculture lxii $^{\text {. }}$ 


\section{2.b Sectoral and socioeconomic impacts of physical climate risks}

\section{2.b.i Economic sectors listed in section 1.a which are most exposed/vulnerable to physical climate risks.}

Earlier, sectors of the Kenyan economy most responsible for its GDP were noted as agriculture, manufacturing, wholesale trade, the financial sector, tourism, the transportation sector, real estate and construction, in decreasing order of their contribution. Each of these sectors is likely to be impacted by climate risks in varying ways which will be discussed below.

\section{2.b.ii Examples of how these sectors may be impacted by climate change including any material impacts on trade flows.}

Agriculture is the mainstay of the Kenyan economy, and it is very vulnerable to climate change due to its reliance on rainfall. There have been increased incidences of drought in Kenyalxxiii, although it is difficult to make direct causation links between climate change and historic droughts. ${ }^{\text {Ixiv }}$ Severely reduced volumes of major rivers, and drying up in some cases, is associated with crop failures, which then increase the risk for hunger, malnutrition and starvation. Crop failures in turn impact manufacturing and trade, the export-import balance ${ }^{\mid x \times v}$ and the ability of the economy to fund its deficit. With increasing drought, the production of crops such as tea, ${ }^{1 \times x v i}$ sugarcane, wheat and maize is reduced, leading to an increased reliance on imports of staples like wheat, maize and sugar; and a reduction in the exportation of crops like tea.

There are multiple impacts of a changing climate on finance, which is also a driver of the economy and is needed to fund climate-resilient growth as well as offset existing debt agreements. One such mechanism is through the impact of climate change on tourism, which is currently contributing to an export surplus in Kenya's service sector. Estimates indicate that $17 \%$ of Mombasa, which currently is a significant contributor to national economic growth, will be submerged if there is even a 0.3-meter increase in sea levels ${ }^{\mid x x v i i}$.

Climate change risks are also creating vulnerabilities in energy supply in Kenya which has witnessed a reduction of its water catchment areas, although this is also related to land use practices. This can reduce the potential for hydropower generation ${ }^{\text {Ixxvii Ixxix }}$. Given that hydropower constitutes $45.3 \%$ of Kenya's electricity generation ${ }^{1 \times x}$, this is 
concerning and will not only directly impact energy creation but also its use for infrastructure and services provision, and ultimately, economic growth. Increased incidence of prolonged droughts will lead to increased recessions in water levels while increased incidences of extreme rainfall events will destroy systems for the generation and distribution of energy.

Another area of the economy where climate risks will have a significant negative impact is the transport and infrastructure sectors. Extreme weather events such as floods and rising sea levels may cause damage to transport and communication infrastructure such as railway lines, road and bridges, while increased temperatures can affect rail tracks, causing them to warp under intense heat. These damages are expensive to fix, especially in the context of the significant infrastructure gaps that already exist in the country. For example, during the 1997/1998 El-Niño rains which lasted for months, the estimated damage to Kenyan transport and telecommunications infrastructure was one billion USD. These damages can further increase the dependence of Kenya on external investors, which can increase its vulnerability to long-term debt arrangements and reduce its ability to finance social, health and education sectors to make its population resilient.

In the Real Estate and Built environment sector, building operational costs are on the rise. For instance, the use of air-conditioning to achieve favourable indoor thermal conditions has been on the rise in Kenya, with reports suggesting that Nairobi's indoor air conditioning sector has passed its peak development phase and entered into a period of constant growth ${ }^{1 \times x x i}$. This, in turn, has exacerbated the building energy demand, and the operational cost of most buildings.

\section{2.b.iii Demographic and ethnographic groups most at risk from climatic changes}

The impact of climate change related risks will not be evenly distributed, and will be most damaging to already vulnerable populations, thus worsening already steep inequalities and reducing population resilience. Once of such groups are pastoral communities $^{\mid x x x i i}$, and particularly the women and youth within them ${ }^{\mid x x x i i i}$. The nature of the ASALs of Kenya has created a culture of pastoralism in response to their aridity and climate variability. Increased variability of these natural conditions due to climate change can make it difficult for them to be contained by the resilience mechanisms 
that pastoral communities have developed to thrive within them. Climate change alters traditional patterns of mobility, modifies their landscapes, affects the balance between water and pasture, increases surface water run-off and moisture of pasture, and reduces the productivity of rangelands.

It was also noted earlier that $80 \%$ of the population in north-eastern Kenya lives below the international poverty line of USD 1.90 a day, almost double the national level of poverty. Another population of concern are those living in poverty, especially in coastal areas which will experience more infrastructure damages, economic vulnerability and diseases associated with flooding. Additionally, in urban areas, the urban poor will compete increasingly with migrants from various communities affected by climate change, worsening intra-urban poverty, the strain on resources and the potential for conflict.

\section{2.b.iv Broader risks to sustainable development within the country/region that arise from physical climate change}

In 2019 , Kenya scored $60.60 \%$ on total progress towards achieving all 17 SDGs and is ranked 118th out of $193^{1 \times x \times i v}$. The physical risks detailed above pose a significant threat to the sustainable development of Kenya, particularly the goal of fostering resilient, inclusive and sustainable growth. This is poignant considering that the impacts of climate change on the country are overwhelmingly disproportionate to its almost negligible contribution to global GHG. It can be anticipated that unless proactive mechanisms are in place, both its economic growth objectives and global sustainable development priorities can be compromised by the physical risks of climate change. This will take place through multiple interacting means, particularly impacting its current growth sectors; increasing reliance on importation of debt, resources and services; thus weakening social and economic resilience; with impacts on population wellbeing and productivity, particularly the most vulnerable.

\section{2.c Adaptation: Solutions \& Opportunities}

2.c.i Country specific adaptation and resilience priorities against anticipated levels of climate change impact 
In cognizance of the impacts of climate change-associated risks on its development trajectory, Kenya has developed a National Climate Change Action Plan (NCCAP) 2018-2022, which also includes a National Climate Change Response Strategy (NCCRS) to adapt to and mitigate climate change ${ }^{\mid x \times x v}$. The NCCAPlxxxvi aims to streamline climate change into the function of diverse sectors with the end goal of ensuring that its development is climate-resilient and low carbon. It is aligned with the United Nations Framework Convention on Climate Change (UNFCCC) as well as Kenya's Big Four Agenda, and the Sustainable Development Goals (SDGs). As part of this plan, the government aims to improve the adaptive capacity of households through improved access to devolved adaptive services, improved adaptive capacity to floods and droughts, and improved agricultural productivity, and improved coordination of the national disaster management response. Based on these goals, the government aims to ensure that Kenya can abate its business-as-usual emission by $32 \%$ in the year 2030 .

\section{2.c.ii Current/future solutions which have the potential to satisfy this country's adaptation needs, including transformation.}

Current and future solutions to achieve Kenya's adaptation need to be in line with the priorities above cover strategies for sectoral transformation, innovative financing priorities, infrastructure provision and information systems. Innovative financing priorities aim to create sustainable mechanisms for capital to be mobilised to address the impact of climate change in Kenya. The Kenyan National Treasury, tasked with implementing the goals of the NCCAP, aims to create the fiscal space to achieve these targets by mainstreaming climate resilience and low carbon growth scenarios into the planning and budgeting approaches at the county and national levels. Additionally, it aims to promote the adoption of climate-friendly technologies through the use of fiscal and policy incentives. It also aims to build the capacity of the government, the private sector, civil society, and marginalised groups to access and report on climate change, while building the confidence of investors by easing legal and regulatory challenges so that the private sector and financial sector can invest in low-carbon and climate resilient investments including Green Bonds ${ }^{1 \times x \times v i i}$. 
Incentives being proposed to enable Kenya's sustainable economy include policies that mandate energy audits being run on industrial consumers and the use of subsidies and tax incentives to ensure that energy efficient gadgets are adopted. Other related goals are the government's plans to create insurance schemes for emergency preparedness in locations prone to climate emergencies, livestock, and crops. IxxviiiThese goals require institutional capacity to be realised in developing coordination mechanisms across the country, improved access to finance options and a strengthened pipeline for innovative finance projects.

Information technology and management tools aim to make the collection of data to mitigate and adapt to climate risks more feasible for communities, specified stakeholders and the government. An example of a proposed solution in this regard is the use of user-centric decision aid tools in understanding the impact of thermal discomfort throughout the 100-year service life of buildings and thus enabling effective adaptations to the risk for overheating. This decision support tool was piloted in office buildings in Nairobi|xxix. In the health sector, surveillance tools have been proposed to investigate and enable rapid responses to outbreaks resulting from climate change, as well as to educate the public.

Infrastructural solutions aim to provide accessible and low-cost solutions to climaterelated challenges. Examples of such proposed projects include the government's plan to improve healthcare infrastructure, to implement integrated natural resource management frameworks, to construct dams and water pans while also building capacity for water quality improvement and efficiency. Solutions are also being proposed to adapt to the impacts of climate change such as physical structures that can withstand high temperatures \& strong winds and food crops that are resistant to drought. Solutions proposed to mitigate climate change impact include the use of energy efficient products, the construction of buildings that require less energy consumption via cooling, biogas fuelled manure production in the agricultural sector, the use of low GHG transport modes, the use of biotechnologies that reduce emissions and increase food production by unit area, amongst others.

\section{2.c.iii Locally specific emerging sectors that might be of future importance for adaptation}


It is estimated that $95-98 \%$ of Kenya's land mass is dominated by its countrysides. ${ }^{\mathrm{xc}}$ Emerging research into the social and cultural perceptions of these countrysides have uncovered that they do not exist on a clear rural-urban dichotomy, but are interlinked with urbanisation, and informed by urban capital ${ }^{x c i}$. An understanding of ongoing transformations of the countryside, their linkages with urban phenomena, and their yet understated processes can provide an asset in addressing local climate-related risks and in adapting to climate change.

Another emerging area of interest is carbon capture and sequestration projects which hold potential benefits for natural resources conservation, biodiversity protection, the restoration of ecologies and the promotion of sustainable development ${ }^{x c i i}$. Africa accounts for only $3 \%$ of the international trade in carbon $\times$ ciii. For these projects to be developed in beneficial ways on the continent including in Kenya, there will be the need for further exploration of mechanisms to ensure that property rights are upheld in ways that benefit host and marginalised populations, that stronger Kenyan capacity to design and implement such projects exists, and that investors can identify promising projects in the region.

Additionally, Kenya's National Construction Authority has been in a process of using participatory approaches to engage the public in revising its building codes, firstly with the private sector, government and professional associations; and secondly through avenues for engagement with the public ${ }^{x c i v}$. There has been an effort especially by the Environmental Design chapter of the Architectural Association of Kenya to establish bio-climatic design guidelines and update the nation's building code, which at the moment only contains guidelines that govern development control. The revision of this Draft Code every five years across all Kenya's settlements presents an opportunity to address climate-related risks in the built environment through the harmonization of relevant laws and regulations.

Other emerging opportunities and developments include COVID-19 related governance transformations such as through the establishment of the National Coordination Committee on Coronavirus Pandemic (NCCCP) ${ }^{\mathrm{xcv}}$. COVID-19 has simultaneously diverted funds away from key infrastructure and services, while also transforming governance in ways that could potentially be harnessed to respond to climate change and should be noted. 
The NCCCP aims to create a coordinated response to the pandemic by evaluating risk levels and advising the government on appropriate measures to be prepared, prevent and respond to public health challenges resulting from the pandemic. Aspects of this heightened coordination mechanism will impact sectors being transformed by climate change. One such is in the area of water provision. Already, floods and droughts have been impacting water resources in Kenya in conjunction with the growing demand for water. Prior to the pandemic, efforts to increase access to water involved increasing water storage capacity via dams. Given the pandemic, a cross-national collaboration process spearheaded by the Ministry of Water, Sanitation and Irrigation led to the mobilization of resources to install water storage tanks, drill boreholes in major urban centres including informal settlements, and to install an estimated 5333 public handwashing points. New collaboration networks may hold the potential to bridge infrastructure, network and resource gaps in adapting to and building resilience to climate change. Key needs in the water sector remain, particularly data and information management systems along with accompanying irrigation and water infrastructure in communities.

Other emerging trends are the use of creative financing approaches to mobilise capital for climate-resilient development ${ }^{x c v i}$. Nairobi, being only one of four African financial centres that include Casablanca, Lagos and Cairo, has joined the Network of Financial Centres for Sustainability in Geneva, which is a partnership of global financial centres to expand sustainable finance. Currently, Africa has issued only $\$ 2$ billion of the $\$ 167.3$ billion green bond issuances globally. One of such programmes is the Green Bonds Programme Kenya, which aims to create a transparent market for green bonds in Kenya. It can be anticipated that such instruments will continue to be developed in Kenya with implications for investment in climate-resilient development.

\section{Development compatible transition - risks, mitigation, and opportunities}

\section{3.a. Socioeconomic and sustainable development risks of a net zero transition}

\section{3.a.i How different demographic and ethnographic groups would be impacted by a net zero transition}

There are several populations that require consideration under a net-zero transition in Kenya. One of these is informal settlements. Approaches informing the need for a sustainable transition often have privileged top-down frameworks and limited 
understandings of science, exclude non-traditional sources of knowledge, and have a bias for more formalised governance networks and arrangements ${ }^{\text {xcvii }}$. The implementation of the global cascaded-down measures recommended by WHO to manage the spread of COVID-19 in informal settlements revealed a stark incompatibility: layering aggressive pandemic management atop the very complex multi-layered reality of informal settlements. Several net-zero implementation plans do not account for the challenges faced by informal settlements, which could lead to more collateral vulnerabilities suffered by this population. Additionally, there are communities such as the Nilotic communities of Northern Kenya, including the Samburu and the Turkana, which still have strong indigenous identities and exist in relatively remote settings, whose social and cultural dynamics have not yet been considered in adapting net-zero scenarios. Additionally, there remains a limited understanding not only of urban and countryside settlements, for which monolithic and reductive ideas exist. Without a better understanding of the interactions between these cultural, spatial, and social structures, a net zero pathway may create unintended negative consequences for these groups and may ultimately not foster the sustainable and inclusive development desired.

\section{3.a.ii Risks to broader sustainable development within the country/region that could arise}

There are significant infrastructural, technical, and governance investments that are necessary to enable a transition to a sustainable economy. Without sufficient political will and financial support to make these possible, there are concerns that they will compromise existing development goals and plans, leading to deficits in budgets, timelines, and expectations. Some of such plans include the Vision 2030xcviii and county level blueprints ${ }^{x i x}$.

Additionally, the financial impact of sector-specific transitions may have cross-cutting impact in terms of economic development, food security, livelihoods ${ }^{c}$ and infrastructural costs. Other concerns relate to not only creating initial systems shifts but also ensuring that assets are maintained at net-zero over time. Furthermore, in an emerging country context where policy networks are homogenous, rapidly changing and often fragmented, there are concerns that the data and evaluation needed to not 
only create but maintain new net-zero scenarios will require the arduous process of building cross-cutting expertise and value chain of training to be feasible. These factors present financial, social, political, and intellectual capital costs that are a challenge in the discourse on net-zero transitions in Kenya.

\section{3.b Just Transition}

\section{3.b.i What are the priorities for enabling a just transition in this country?}

It has been previously mentioned that the transition to a net zero economy will have to take into consideration the needs of disparate sectors and communities to ensure inclusion and the achievement of diverse sustainable development goals. Achieving a just transition that prioritises equity in transitioning the economy and introduces human rights considerations into the provision of resources to address climate change ${ }^{\text {ci }}$ opportunities and the needs of marginalised populations should be prioritised. For example, an adaptive climate pathway could be integrated with the need to improve education rates across the country.

An example of how this has been done is the The Kazi Mtaani program ${ }^{\text {cii. }}$ This program aimed to target youth employment across the country and more specifically youth residing in informal settlements, to engage them in activities in improving their environments, while cushioning them from the economic strain. This was particularly important considering the spread of the coronavirus which necessitated containment strategies and inevitably contracted economic activity. These impacts were most severe for low-income earners who rely on their daily income to meet their household needs and live in areas with limited resources. Therefore, this was seen as an opportunity to apply Extended Public Works Programs (EPWPs) to achieve multiple aims of providing employment through daily wages for low-income workers across the country while improving infrastructure and service delivery. Future approaches to youth empowerment in urban slums could extend this program by targeting rural youth as well, and paying them to tend trees to maturity while also involving them in activities such as water harvesting, catchments protection, supplying water, solarizing schools among other climate change adaptation and resilience building activities. 
Now on its $8^{\text {th }}$ month of implementation, this program is likely to be turned into a countrywide employment program that ensures job security and sustained livelihoods as Kenya moves on to the COVID-19 recovery and resilience building phase. Projects such as these that build on countryside networks and populations to create employment, extend not only infrastructure provision, but also solid waste management, greening and urban agriculture. The program has substantially built and diversified the spatial spread of skills to these youthciii. Given the spread of information and communication technologies, such programs can be used to integrate more marginalised populations and work with them to implement the net-zero pathway while also improving job stability with the inevitable economic transitions that a net zero scenario will entail. Already, Kazi Mtaani Youth have been mobilised in the creation of COVID compliant schools using stabilised earth blocks. In the first month of the program, 554,876 tonnes of garbage were collected from informal settlements across the country, 166,294 trees were planted and 1.6M trees in nurseries were set up across the country. This illustrates that these groups can also be mobilised in planting trees and collecting waste in informal settlements which experience hotter micro-climates, among other possibilities. Such approaches will contain the costs associated with managing and implementing diverse programs to transform Kenya into a net-zero economy.

\section{3.b.ii What are some examples of future opportunities that could enable a just transition in this country, including adaptation to transition risks?}

Recent examples also demonstrate the potential to integrate community needs into the preservation of ecological resources along the net-zero pathway ${ }^{\mathrm{civ}}$. These include efforts to secure mountain forest ecosystems such as Rhino Ark that train and then enlist the services of communities in conservation through i) educating communities about conservation ii) channelling funds for conservation to also preserve communities e.g., by protecting them from human-wildlife conflicts through fencing. The Mt. Kenya electric fence for example, is estimated to protect about 80,000 households from the threat of human/wildlife conflict. Agroforestry projects also have the potential to be a win-win for small-scale farmers and climate change mitigation. For example, projects like the BioCarbon Fund ${ }^{\mathrm{cv}}$ worked with farmers to store carbon dioxide in trees and the 
soil, while rewarding them for this service in the reduction of greenhouse gas emissions in the form of payment for carbon credit sold. This project helped to strengthen farmers' skills in sustainable land management, availing them of improved agricultural methods that could increase their harvests and their income. Such projects achieve the triple aim of improved food security, increased productivity and increased income for farmers. They also directly contribute to gender equality, given the popularity of rural agriculture for women in several communities.

3.c Sectoral and socioeconomic impacts of a development-compatible transition under each of the following transition pathways

- Steady, orderly, persistent transition pathway

- Late, disorderly transition pathway

\section{Sectoral Impacts}

The following part of the profile will be split by sectors defined by the Expert Committee as priority sectors of key importance towards a net-zero transition. For each of these sectors in turn, the following questions are answered:

\section{3.c.i Sectors most likely to be impacted, including material impacts on trade-} flows, and considering both risks and opportunities.

Even though the immediate impacts of climate change are already being experienced, everyday insecurities around livelihoods will continue to take precedence over longer term scenarios for a sustainable future, unless they are aligned. The primary concerns associated with transitioning to net-zero pathways include the socioeconomic impact and the inadequacy of political and financial capital to make this pathway feasible with development goals and urgent present-day livelihoods concerns. Additionally, the topdown focus of most frameworks without an adequate understanding of the experiences and perceptions of the Kenyan population presents a challenge in adopting transitions to the net-zero scenarios. For example, transition to energy efficient materials in the built environment will pose a challenge for developers, in the absence of adequate subsidies and incentives. Likewise, in the absence of specific data systems to understand not just the global but the Kenyan context, net-zero 
approaches risk neglecting the social, economic and cultural context of the population, with possible unintended consequences especially from the informal economy, pastoral population, and low-income segments of the population.

\section{3.c.ii Examples of how these sectors may be impacted by a net zero transition including any material impacts on trade flows.}

This section could use tables (one per sector) showing the impacts of transition risk drivers on the sector in question.

Below are examples of anticipated impacts of a net zero transition on key sectors of the Kenyan economy:

Agriculture: A net-zero transition will require that the agricultural sector is made climate-resilient while also reducing its impact on the climate. Changes along a netzero pathway can be expected to include the use of crop varieties that are more resistant to climate change effects such as drought; crop cvi and manure production using more sustainable energy sources e.g., biogas; efficient irrigation systems, water harvesting and storage technologies, the use of energy efficient farm machinery, transitioning away from firewood, and embracing of agroforestry and woodlot to increase on-farm and household tree cover. Additionally, land use governance practices that allow for integrated natural resource management while also enabling adequate resource sharing among livestock producers particularly pastoralist communities in the ASALs are needed. Risks that can be anticipated include increased financial expenditure that may be passed down to consumers, and for which the brunt will be borne the most by already food insecure populations. However, a global latestage transition will incur the risk of devastating the country's exports of crops as rainfall patterns become more erratic. 
Building, Infrastructure and Construction sector: Infrastructural investments along a net-zero pathway require solutions that can mitigate or adapt to existing climate challenges while meeting development needs. This can be achieved with energy production sources that are renewable cvii e.g., wind and solar to run manufacturing, household, irrigation and commercial processes. Evidence suggests that aspirations along this pathway could include the implementation of policies to transform building codes, land use regulations and built environment design requirements to ensure that new developments are sustainable ${ }^{\text {cviii }}$, to adapt old buildings, and to mainstream climate-resistant building materials. Risks that can be anticipated include: land use transformation to capture land for carbon sequestration or sustainable energy production may not be cognizant enough of social and cultural dynamics and may exacerbate marginalization. However, a global late transition will lead to increased temperatures, indoor overheating and increasing infrastructural damages due to changing weather patterns.

Health: In the health sector, proactive approaches to public health that balance current health challenges such as malaria, with long-term challenges such as pandemics will be needed along a net-zero pathway ${ }^{c i x}$. Additionally, health investments that go beyond healthcare siloes to integrate climate change considerations will be needed. For example, investments in urban greenery to reduce overheating, or the investment in mixed-land use development and non-motorised modes of transports will have wins for both health, health behaviours and climate-proofing communities, and should constitute typical approaches. This will require perspectives about health that are no longer reactionary but proactive ${ }^{c x}$ and anticipate climate change health risks e.g., flooding, pandemics, food security, infections, and catalyse coordinated approaches to reduce the downstream burden on healthcare systems by investing in upstream prevention of disease. This will also necessitate creative partnerships with multiple players and a health workforce able to balance the short-term perspective on health challenges with long-term perspectives on their upstream drivers. Particularly, this will necessitate a move to more community-centred and prevention-focused approaches to health. Risks that can be anticipated are that this approach may clash with more hospital-centric and medical conceptions of public health, as well as industry motives in sectors that impact on poor health outcomes e.g., infrastructure projects that cause injuries or agricultural projects that increase disease and/or food insecurity. However, 
a late-stage transition will incur the risk of creating a demand for healthcare services that far surpass the reasonable supply due to health risks associated with overheating, pandemics, water-borne infections, amongst several other health risks of climate change.

Finance: The financial services sector can expect significant changes in the form of new products to deal with climate risks e.g., mobile-based financing instruments to provide insurance for high-risk locations and communities, cxifinancial tools to adapt to climate change e.g., bonds, as well the potential growth of environmental, social and governance criteria for investors who are introducing capital into the market. Within the national economy, policy tools will necessitate the creation of tax incentives, audits and subsidies to shape markets such that investments in sustainable transitions are feasible. Risks that can be anticipated are that these tools may not be well designed for the Kenyan context and may have unexpected or unconsidered long-term effects. However, a late-stage transition will ensure that there is no feasible development trajectory that Kenya can follow toward creating a sustainable economy.

Across these fore-mentioned sectors and more, what remains clear is that there are opportunities and risks associated with the change to a net-zero economy. What will make this transition have a net-positive impact is the robustness of the evidence that informs approaches, the extent to which they are continually evaluated, the thoroughness of the consideration given to both long and short-term impacts of the transition on diverse populations within the country, and the extent to which approaches are cross-cutting, coordinated with the public, and maintained.

\section{3.d Development-compatible emissions: Solutions \& Opportunities}

\section{3.d.i Current/future solutions that can enable development-compatible emissions reduction in the country (in line with the SDGs).}

Future solutions can build on ecological and community assets to enable development-compatible emissions in Kenyacxii. For example, rather than rely exclusively on design, technology and renovation-related opportunities in cities, adjacent spaces can be tapped as resources for climate change adaptation. Three 
major Kenyan cities namely Nairobi, Mombasa and Kisumu are adjacent to spaces which can serve as carbon sinks. In Nairobi, Nairobi National Park with an area of $117 \mathrm{~km}^{2}$ compared to the $696 \mathrm{~km}^{2}$ occupied by Nairobi provides an asset that could potentially be even more equipped, via populating it with trees, to absorb carbon. The coastal location of Mombasa city near the ocean and its coral reefs, both of which are carbon sinks, also presents opportunities for these interlinkages. Likewise, Kisumu's city Lake Victoria is eutrophic. cxiii With the potential of eutrophication to create carbon sinks, assets may also exist in this natural resource for addressing climate change risks cxiv.

Along with the national mainstreaming of climate change into diverse sectors that is already ongoing, sectoral carbon-reduction blueprints can be developed for key sectors of the national economy e.g., the built environment ${ }^{\mathrm{cxv}}$, construction,

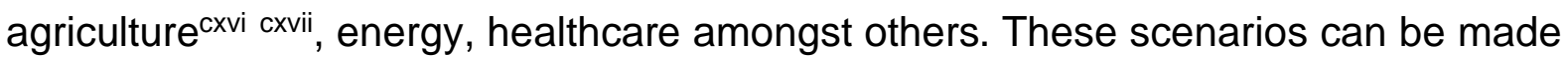
feasible by framing them in light of local values and social and cultural dynamics rather than using a purely technological or design-oriented framing.

Solutions should draw upon rural-urban interlinkages to create more sustainable adaptation and mitigation solutions. Flows of capital, people and resources continually occur between urban and country-side settlements and this linkage will need to be explored to uncover unique opportunities to address climate change in Kenya. Table 1 below ${ }^{\text {cxviii }}$ provides an example of complementary opportunities to create an integrated approach to climate change by looking at the spaces between, beside and beyond cities.

Table 1

\begin{tabular}{|l|l|l|}
\hline & Countryside & Urban \\
\hline $\begin{array}{l}\text { Causal space of } \\
\text { change }\end{array}$ & $\begin{array}{l}\text { Deforestation } \\
\text { Intensive farming } \\
\text { Mining sites }\end{array}$ & $\begin{array}{l}\text { High energy consumption } \\
\text { Transportation networks } \\
\text { Use of fossil fuels } \\
\text { Waste disposal }\end{array}$ \\
\hline
\end{tabular}




\begin{tabular}{|c|c|c|}
\hline Effects/Climate Risks & $\begin{array}{l}\text { Drought } \\
\text { Disturbed ecosystems } \\
\text { and biodiversity } \\
\text { Land shortage }\end{array}$ & $\begin{array}{l}\text { Overheating risk } \\
\text { Flooding } \\
\text { Water shortage }\end{array}$ \\
\hline \multirow[t]{2}{*}{$\begin{array}{l}\text { Solution space for } \\
\text { mitigation + } \\
\text { adaptation + } \\
\text { resilience }\end{array}$} & $\begin{array}{l}\text { Afforestation } \\
\text { Installing renewable } \\
\text { energy parks }\end{array}$ & $\begin{array}{l}\text { Adaptation of the built } \\
\text { environment to overheating } \\
\text { and flooding } \\
\text { Built environment mitigation } \\
\text { strategies } \\
\text { Renewable energy } \\
\text { Recycling } \\
\text { Sustainable infrastructure }\end{array}$ \\
\hline & $\begin{array}{l}\text { Expansive spaces for } \\
\text { solar and wind farms } \\
\text { (e.g., Turkana wind } \\
\text { farm and Garisa solar } \\
\text { farm) } \\
\text { Linking indigenous data } \\
\text { monitoring systems to } \\
\text { centralized data } \\
\text { systems to inform } \\
\text { community-driven } \\
\text { resilience to climate } \\
\text { change } \\
\text { Public-private } \\
\text { partnerships to improve } \\
\text { access to risk-pooling } \\
\text { resources for }\end{array}$ & $\begin{array}{l}\text { Enhanced Urban food farming } \\
\text { (examples such as hydroponic } \\
\text { farming) to manage } \\
\text { implications of drought. } \\
\text { Enhancing Biodiversity } \\
\text { through urban design } \\
\text { strategies enhancing the } \\
\text { ecology of the space in } \\
\text { between buildings. } \\
\text { Proactive development of } \\
\text { infrastructure to inform } \\
\text { preparedness (e.g data } \\
\text { systems), response to (e.g } \\
\text { tracking of floods), and } \\
\text { recovery from climate-related } \\
\text { disasters (e.g evacuation }\end{array}$ \\
\hline
\end{tabular}




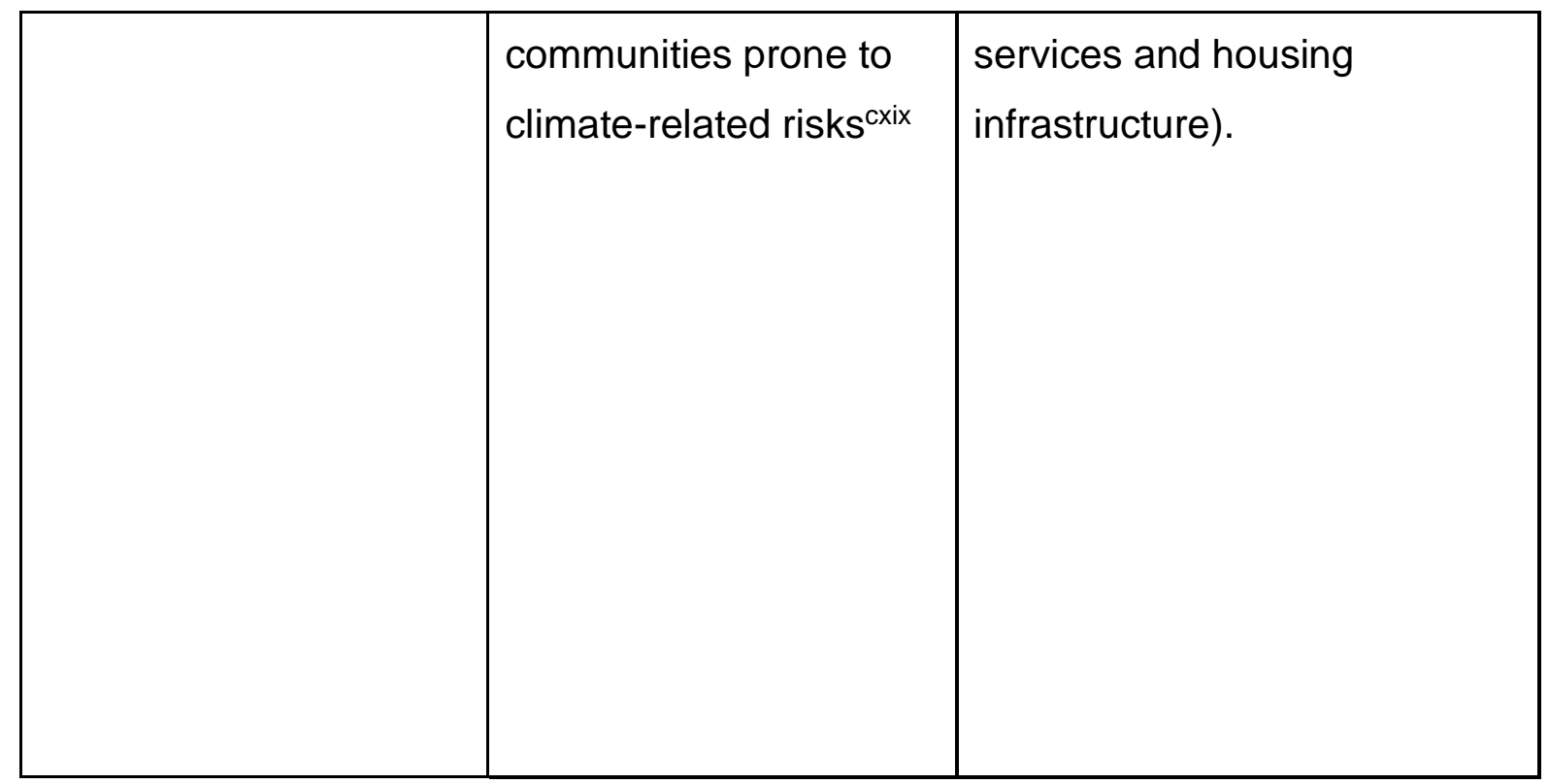

With these interlinkages in view, new untapped opportunities emerge.

Opportunities also exist in moving beyond the modern conceptions of place to their complication by informality which is the substance of the Kenyan economy. Table 2 below notes the distinctions in public perceptions of informality in the Kenyan context. Considering that informality is the status quo rather than the exception in Kenya, housing about $60 \%$ of the population in Nairobi for example, the opportunities to understand the drivers of and opportunities to address climate change have not been optimised.

\section{Table 2}

\begin{tabular}{|l|l|l|l|}
\hline $\begin{array}{l}\text { Informal } \\
\text { businesses }\end{array}$ & Informal settlements & Formal businesses & Formal settlements \\
\hline
\end{tabular}




\begin{tabular}{|c|c|c|c|}
\hline $\begin{array}{l}\text { Not registered and } \\
\text { have their basis } \\
\text { on individual effort } \\
\text { and small } \\
\text { enterprises. } \\
\text { They mainly } \\
\text { remain } \\
\text { unprotected by } \\
\text { labour-related } \\
\text { regulations and } \\
\text { mostly lack social } \\
\text { security. } \\
\text { processes. } \\
\text { There is a shared } \\
\text { scholarly view that } \\
\text { both informal } \\
\text { settlements and } \\
\text { informal } \\
\text { businesses often } \\
\text { fill the void left by } \\
\text { formal } \\
\text { urbanisation } \\
\text { the of the } \\
\text { prom }\end{array}$ & 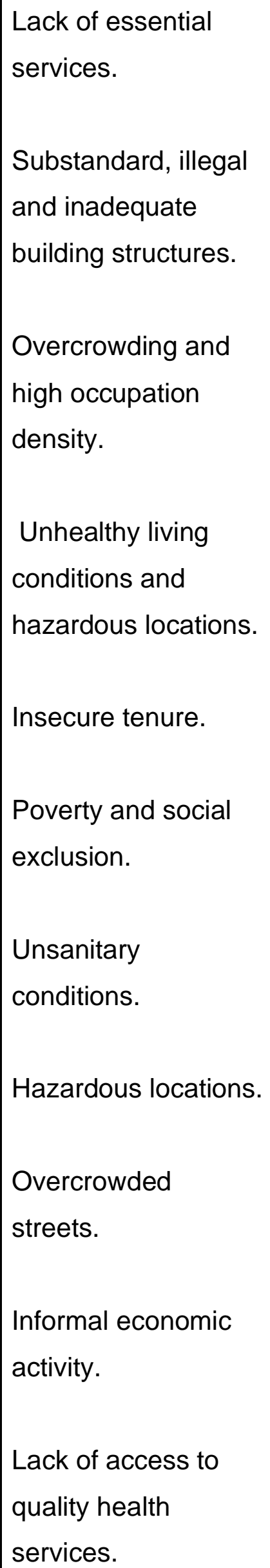 & $\begin{array}{l}\text { Registered. } \\
\text { Regulated by } \\
\text { statutory } \\
\text { frameworks. } \\
\text { More often align to } \\
\text { the functionalist } \\
\text { paradigms based } \\
\text { on the idea of a } \\
\text { centralised and } \\
\text { mostly hierarchical } \\
\text { control of a city. }\end{array}$ & $\begin{array}{l}\text { At least partially } \\
\text { served by } \\
\text { government } \\
\text { service provision } \\
\text { Building structures } \\
\text { required to comply } \\
\text { to legal standards } \\
\text { Lower occupation } \\
\text { density } \\
\text { Formal tenure } \\
\text { arrangements } \\
\text { settlements } \\
\text { informal } \\
\text { Improved sanitary } \\
\text { conditions due to } \\
\text { improved access } \\
\text { to services and } \\
\text { infrastructure } \\
\text { hreater access to } \\
\text { health services } \\
\text { Lower levels of } \\
\text { ine compared to }\end{array}$ \\
\hline
\end{tabular}




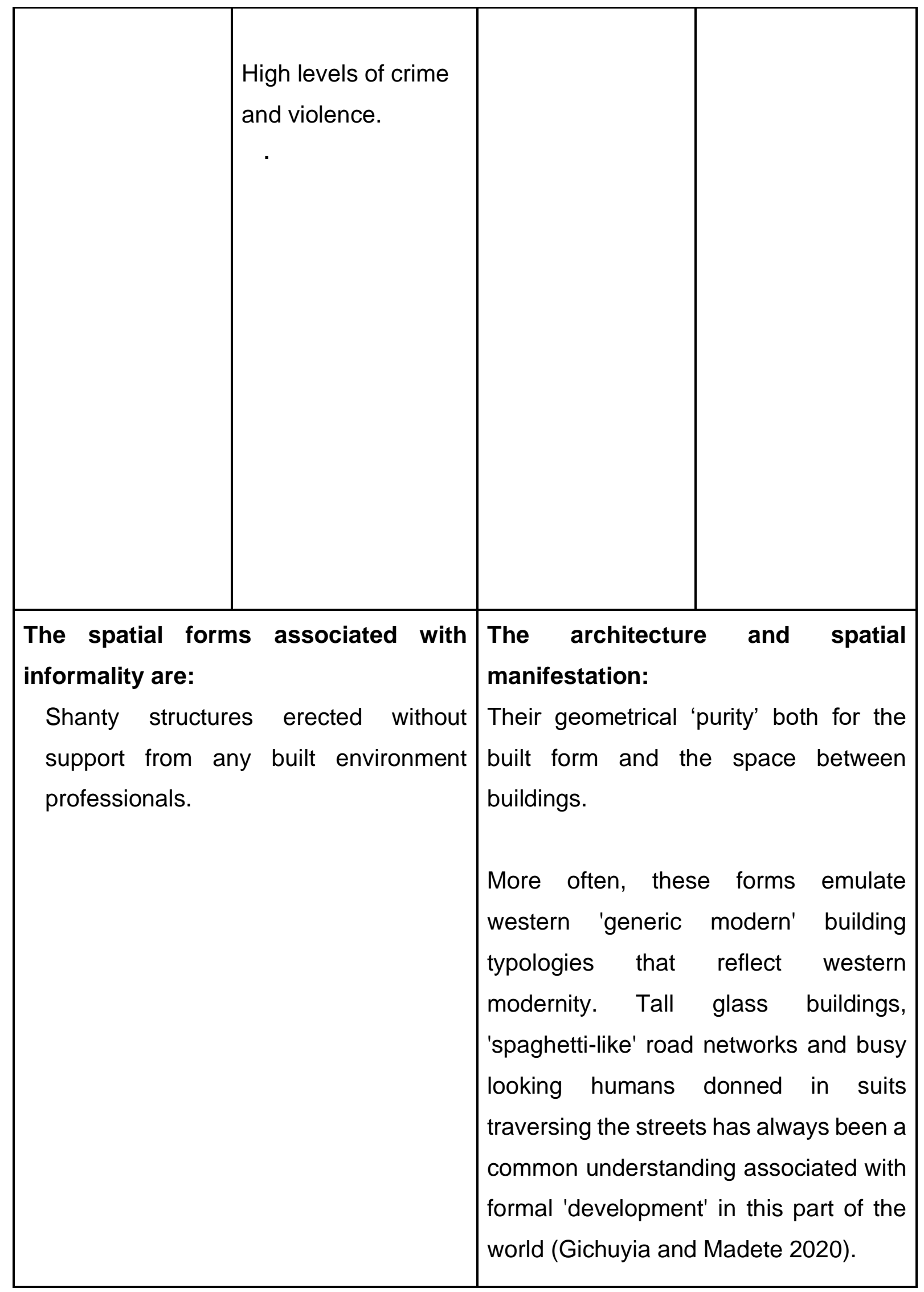

The drivers of climate change in Kenya's informal settlements are distinct from those in formal settlements. Technical aspects of the built forms, the configuration of indoor 
spaces, the uses of building all have an impact on the microclimate of informal spaces, making them about $2-3^{\circ} \mathrm{C}$ warmer on average than formal settlement microclimates. The impacts of these microclimates on occupants' thermal comfort as well as the nature of networks and decision-making nodes in informal settlements also differ from formal spaces. However, they also provide complementary and interlinked networks that fuel life and resource provision in communities. Another unique feature of urbanization patterns in Kenya is dynamism beyond classical assumptions of urbanization, toward more fragmented and scaled understandings of neighbourhoods. These present opportunities to create multi-local, and multi-scalar visions for net-zero futures for the country. This move from homogenous to fragmented, complementary and heterogenous net-zero futures are opportunities that need to be further explored $^{\mathrm{cxx}}$.

\section{3.d.ii Locally specific emerging sectors that might be of future importance for development-compatible mitigation.}

There are already ongoing efforts that both spur development and can help with the reduction of emissions in Kenya. Some of these key opportunities for developmentcompatible emissions reductions are discussed below:

\section{1) The transformation of key value chains in the economy:}

Across diverse value chains of the economy, there is a need to disincentivise tools and resources that have higher emissions footprint and instead encourage the use of economic and service inputs and outputs that create a lower emissions footprint. Across sectors, the use of climate-resilient practices coupled with technologies and the emissions reduction in export supply chains ${ }^{\text {cxxi }}$ can help to reduce industrial and local emissions. For example, it is estimated that Kenya's Climate Smart Agriculture strategy (KCSAS) cxxii if properly implemented can lead to emissions reductions from an expected $37 \mathrm{MtCO}_{2} \mathrm{e}$ to $30 \mathrm{MtCO}_{2} \mathrm{e}$ in 2026. Being a signatory of the United Nations Framework Convention on Climate Change, Kenya's government has charted a climate-smart agricultural pathwaycxxii cxxiv with the goals of adapting and building climate change resilience, reducing and/or removing greenhouse gas emissions and improving incomes and productivity ${ }^{\mathrm{cxxv}}$. These commitments require a mix of changed livestock rearing ${ }^{\mathrm{cx} x \mathrm{i}}$ cxxvii and farming practices such as the use of intercropping and 


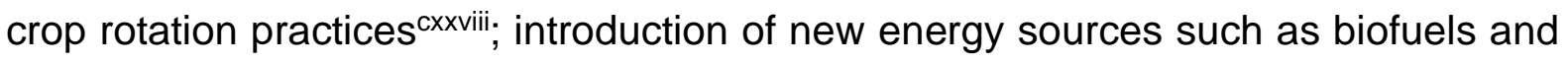
renewable sources; the use of new inputs and technologies e.g., improved fertilisers $^{\text {cxxix }}$ and insect-based feed ${ }^{\text {cxxx cxxxi }}$.

\section{2) Multi-local scenario building and solutions:}

The opportunities to create alternative scenarios for the microclimate of informal settlements within cities has been earlier discussed, as well as the opportunities to explore the value of rural areas, lakes, and landscapes that are adjacent to cities in a complementary fashion. Multi-local solutions present complementary and development-compatible opportunities unique to the Kenyan context. These require complementing the rural and urban, settlements and their adjacent ecological resources, intra-rural and intra-urban microclimates, and the informal and the formal economies.

An additional opportunity exists in expanding the transformation of value chains beyond the formal sector, especially given the informal-centred economy of Kenya. Given that several economic players lie in the informal sector, approaches for gathering data on their value chains, their impact on the economy, and their impact on natural resources can help to understand how to reduce emissions. One example is the energy sector for which charcoal, a bioenergy resource, whose value chain is largely informal, plays a key role. Charcoal contributes to energy generation in an estimated $82 \%$ of urban and $34 \%$ of rural Kenyan households and also employs an estimated 1 million people in some capacity. However, it is also a well-known driver of the depletion of forestry resources. This sector's value chain is informal and thus, under-explored from an investment point of view. As such, opportunities to transform it toward sustainability, while also exploring other bioenergy options e.g., animal wastes, and crop residues ${ }^{\text {cxxxii }}$ have been underutilised.

Currently, the Kenya Forestry Research Institute is working on research to improve tree varieties with an emphasis on improved growth and drought resistance, while also generating smokeless briquettes to transform charcoal production, and technologies to improve saws and thus timber recovery from $30 \%$ capacity to $56 \%$ cxxxiii. Formal and informal value chain transformation will illuminate policy and legal opportunities to drive investments to them that will transform their inputs and outputs sustainably, while also setting boundaries that discourage resource depletion. This opportunity will also be development-compatible given that most of the economy is driven by the informal 
sector. Such initiatives can target value chain creation in the informal sector on a climate adaptive trajectory, drawing inspiration from projects such as the Women Enterprise Fund which creates micro-financing opportunities for women, the Poverty Eradication Fund, and the Njaa Marufuku Kenyacxxiv cxxxv initiative focused on supporting groups with livestock rearing. The Greenbelt Movement founded in 1977 by Professor Wangari Maathai has also planted over 51 million trees in Kenya, simultaneously promoting environmental conservation; building resilience, fostering democracy and livelihoods ${ }^{\mathrm{cx} x \mathrm{xv}}$. There are also several ongoing efforts to increase the demand and supply of climate-start technologies in Kenya, with partnerships with the private sector and international organizations to finance and promote the adoption of these technologies ${ }^{\mathrm{cx} x x v i i}$.

\section{3) Institutional strengthening to enable coordinated, science-informed and locally driven strategies}

Reducing carbon emissions in Kenya requires extensive implementation and coordination efforts that are technically sound, contextually relevant and are continually monitored. There is an opportunity to continue to strengthen the government's capacity to enable this work, especially given its National Climate Change Response Strategy. Activities of specific relevance for the reduction of carbon emissions include initiatives such as the School Green Initiative being implemented by the Ministry of Education and Ministry of Health to use land in learning institutions in partnerships with students to grow and sustain trees. Such initiatives require rapidly evolving data that is not only top-down but bottom-up. In this regard, there are also opportunities to support appropriate data generation systems and fully integrate them into governance. They include, for example, equipment and technologies as well as analytical and interpretive capacities to monitor weather data and disseminate it to relevant agencies as well as the public. Another example is the initiative by the Kenyan Forest Service to track agencies and community projects benefiting from carbon credits. 


\section{4) Market creation:}

There are opportunities to create new market opportunities out of carbon emissions reduction in Kenya. However, these require financial products, tools and service provision suited to the Kenyan context. When explored and enhanced, these opportunities can create "pull" effects to drive carbon reduction. These include opportunities to support small-scale farmers and communities to benefit from the positive impact of wildlife conservations via ecotourism, as well as from carbon sequestration ${ }^{\mathrm{cx} x \mathrm{xvii}}$ through carbon credits, and supporting climate-resilient horticulture ${ }^{\text {cxxxix }}$. Several of these opportunities will need to be supported by appropriate standards, such as building code requirements, industrial product certifications and standards as well as accelerated pathways for the approvals for goods and services which are created to suit ecological requirements.

Examples of ongoing activities include:

the work of the Kenya Bureau of Standards to develop and enforce standards for goods and services and then improve their access to local and international markets.

- $\quad$ efforts to improve the energy efficiency of equipment and appliances in residences and the industrial sector in the $E A C$ in order to reduce carbon emissions.

- $\quad$ efforts to spearhead green innovation by the Ministry of Industrialization, supporting the informal sector to make energy saving stoves and jikos, and mats, baskets and furniture out of water hyacinths.

promotion of cleaner production technologies through the provision of technical support via the Kenya National Cleaner Production Centre to reduce wastes generated in the use of raw materials, water, and energy resources.

- decongestion of vehicular transport through improved use of non-motorised transport options and improving commuter efficiency through higher quality and capacity vehicles.

- $\quad$ practices in the private sector to reduce waste, such as the promotion of eco-friendly cartons for packing household goods, incentives for the reuse of 
plastic bags, and the promotion of biodegradable plastic bags by merchants, and efforts to reduce waste generation and energy use in office buildings ${ }^{\mathrm{cxl}}$.

\section{5) Global capital mobilization:}

There are emerging opportunities to ensure that Kenya can mobilise capital that is available for carbon reduction globally. These will attract funds for development while also reducing emissions. One prominent avenue for this is through carbon markets, which would allow the government to sell certified emission reduction (CER) credits to richer countries that would like to mitigate climate change. These CERs are traded through the Clean Development (CDM) mechanism of the Kyoto Protocol. To strengthen Kenya's ability to do so, tools to integrate these markets into legal and banking systems will need to be strengthened. Other avenues for attracting capital to emission reduction will include strengthening technical capacity for banks to embed sustainability considerations into the ESG risk assessment and the provision of capital.

\section{3.e Likely co-benefits and trade-offs of the solutions and opportunities identified, including, where relevant, in the context of the Sustainable Development Goals.}

Potential mitigation and adaptation pathways can provide trade-offs for diverse communities, as detailed above. Particularly, there is a need to ensure that marginalised communities' needs such as pastoral communities or the informal sector players are not side-lined in the creation of a green economy and the repurposing of governance arrangements and resources such as land to fuel this vision. Additionally, it will be pertinent to ensure that financing arrangements and technological investments do not further exacerbate major inequalities in the country but incorporate the long-term wellbeing of the economy, as well as considerations for spatial and economic equity in their design.

However, it can also be anticipated that these pathways can provide cross-cutting cobenefits. Some of these sector-specific cross-cutting benefits are spotlighted below:

Agricultural benefits: a successful transition can help to improve the resilience of the Kenyan agricultural sector, ensuring the stability or potential improvement in exports. Additionally, it can help to reduce reliance on imports for food supplies. The technical 
expertise developed in climate-proofing of agricultural practices and inputs can also constitute an in-demand skill supply that is globally competitive.

Health benefits: benefits in the agricultural sector can translate to improved food security as well as improved dietary practices due to reduced reliance on highly processed imported food items. Transformation of the built environment through multimodal forms of transportation and through mixed and compact land use can contribute to improved air quality, improved health behaviours such as physical activity which will help to reduce the burden on the health system in the form of chronic diseases. Additionally, efforts to climate-proof settlements through resilient infrastructure, improved resource management, and design considerations can help to prevent disease from climate risks such as flooding and injuries associated with resource conflicts.

Social and physical infrastructure: Several climate-proofing interventions will make spaces more conducive for social interactions which are related to improved health and wellbeing. From green buildings to parks and green spaces, and building designs to reduce overheating, these can be conducive to psychological well-being, productivity, reduced energy costs, and comfort in and outside of buildings.

Economic benefits: There are numerous direct and indirect economic benefits that can accrue from a resilient net-zero transition. They could include improved tourism as a result of reduced catastrophic climate incidents and improved biodiversity, the creation of jobs in the sustainability sectors for young people ${ }^{\text {cxli }}$, inclusion of women and the informal sector, improved exports of skills and outputs, reduced infrastructural losses and thus improved savings, as well as the improved capacity to offset debts and reduced reliance on unfavourable debt instruments due to economic prosperity. 


\section{Definitions of key terms}

Mitigation The lessening of potential adverse impacts through actions that reduce hazard, exposure, and vulnerability.

Adaptation The process of adjustment to actual or expected climate change and its effects, in order to moderate harm or exploit beneficial opportunities.

Resilience The ability of a system and its component parts to anticipate, absorb, accommodate or recover from the effects of a hazardous event in a timely and efficient manner while retaining the same basic structure and ways of functioning, the capacity for self-organization and the capacity to adapt to stress and change.

Vulnerability The degree to which a system is susceptible to, or unable to cope with, adverse effects of climate change, including climate variability and extremes.

Risk The potential for consequences where something of value is at stake and where the outcome is uncertain, recognizing the diversity of values. Risk is often represented as probability or likelihood of occurrence of hazardous events or trends multiplied by the impacts if these events or trends occur.

\section{Acknowledgements}

This country profile was written by Dr Ebele R.I. Mogo (University of Cambridge, UK), with the input from in-country academic experts Prof John M. Wesonga (Jomo Kenyatta University of Agriculture and Technology, Kenya) and Dr Linda Nkatha Gichuyia (University of Nairobi, Kenya), in the context of the BEIS COP26 Futures We Want project. The production of the document was supported by project teams at Cambridge Zero (University of Cambridge, UK) and Deloitte. The authors thank Prof Bancy M. Mati (Jomo Kenyatta University of Agriculture and Technology, Kenya) and Tammy Janes (Met Office, UK) for their reviews, which significantly improved the quality of this manuscript. 


\section{References}

i Republic of Kenya. The National Treasury and Planning. State Department for Planning. (2019). Implementation of the Big Four Agenda. Available at:

https://monitoring.planning.go.ke/wp-content/uploads/2020/10/Big-Four-AgendaReport-2018 19.pdf

iWTO. (2019). Kenya. Available at: https://www.wto.org/english/tratop e/tpr e/s384$\underline{02 \text { e.pdf }}$

iiiWorld Bank. (2019). Kenya. Available at: https://data.worldbank.org/indicator/NY.GDP.FCST.CD?locations=KE

iv Humanitarian Data Exchange. (2021). Available at:

https://data.humdata.org/dataset/kenya-gross-county-product-gcp-by-economicactivities-per-county/resource/f549cb0f-a7ba-4086-967d-4ad8347b1ab0

${ }^{v}$ Humanitarian Data Exchange. (2021). Kenya. Available at:

https://data.humdata.org/dataset/5d7595e8-d66e-49b3-8715-66eedd87a170

vi World Trade Organization. (2019). Annex 2 Kenya. Available at: https://www.wto.org/english/tratop e/tpr e/s384-02 e.pdf

vii Institute of Economic Affairs Kenya. (2012). The informal sector and taxation in Kenya. Available at: https://www.wto.org/english/tratop e/tpr e/s384-02 e.pdf

viii OECD iLibrary. (2019). Tackling vulnerability in the informal economy. Available at: https://www.oecd-ilibrary.org/development/tackling-vulnerability-in-the-informaleconomy 103bf23e-en

${ }^{i x}$ Market Business News. (2021). Informal sector - definition and meaning. Available at: https://www.wto.org/english/tratop e/tpr e/s384-02 e.pdf

${ }^{x}$ Institute of Economic Affairs Kenya. (2012). The informal sector and taxation in Kenya. Available at: https://www.wto.org/english/tratop e/tpr e/s384-02 e.pdf

xi World Trade Organization. (2019). Annex 2 Kenya. https://www.wto.org/english/tratop e/tpr e/s384-02 e.pdf

xii http://www.hubrural.org/IMG/pdf/minot_ngigi_2004.pdf

xiii Government of the Netherlands. (2020). Climate smart Agriculture - Opportunities in the Kenyan Horticulture Sector. Available at:

https://www.agroberichtenbuitenland.nl/landeninformatie/kenia/documenten/rapporte n/2019/11/20/climate-smart-agriculture-opportunities-in-the-kenyan-horticulturesector $^{\text {xiii }}$ 
xiv World Trade Organization. (2019). Annex 2 Kenya.

https://www.wto.org/english/tratop e/tpr e/s384-02 e.pdf

xv United Nations Conference on Trade and Development. (2018). World Investment Report 2018. Available at: https://unctad.org/webflyer/world-investment-report-2018 xvi OEC. (2019). Available at: https://oec.world/en/profile/country/ken

xvii Atlas of Economic Complexity. (2021). What did Kenya export in 2019? Available at:

https://atlas.cid.harvard.edu/explore?country=116\&product=undefined\&year=2019\&p roductClass=HS\&target=Product\&partner=undefined\&startYear=undefined

xviii United Nations Development Programme. (2020). Human Development Report 2020. Available at:

https://atlas.cid.harvard.edu/explore? country=116\&product=undefined\&year=2018\&p roductClass=HS\&target=Product\&partner=undefined\&startYear=undefined

xix World Trade Organization. (2019). Annex 2 Kenya.

https://www.wto.org/english/tratop e/tpr e/s384-02 e.pdf

xxNational Treasury and Planning State Department For Planning. (2020). Second Voluntary National Review on the Implementation of the Sustainable Development Goals. Available at:

https://sustainabledevelopment.un.org/content/documents/26360VNR 2020 Kenya $\underline{\text { Report.pdf }}$

xxi Food and Agriculture Organization of the United Nations. (2021). FAOSTAT. Available at: http://www.fao.org/faostat/en/\#data

xxii World Economic Forum. (2020). Global Competitiveness Report Special Edition 2020: How Countries are Performing on the Road to Recovery. Available at: https://www.weforum.org/reports/the-global-competitiveness-report-2020

xxiii The World Bank. (2021). GNI per capita, Atlas method (current US\$) - Kenya. Available at: https://data.worldbank.org/indicator/NY.GNP.PCAP.CD?locations=KE

xxiv The World Bank. (2018). Poverty Incidence in Kenya Declined Significantly, but Unlikely to be Eradicated by 2030 . Available at:

https://www.worldbank.org/en/country/kenya/publication/kenya-economic-updatepoverty-incidence-in-kenya-declined-significantly-but-unlikely-to-be-eradicated-by2030

xxv Kenya National Bureau of Statistics. (2021). Key Indicators at a Glance. Available at: https://www.worldbank.org/en/country/kenya/publication/kenya-economic-updatepoverty-incidence-in-kenya-declined-significantly-but-unlikely-to-be-eradicated-by$\underline{2030}$

xxvi Sustainable Development Report. (2021). Kenya. Available at: https://dashboards.sdgindex.org/profiles/kenya 
xxviiThe World Bank. (2021). Kenya. Available at:

https://data.worldbank.org/country/KE

xxviii The Republic of Kenya. (2019). Third National Reporting Indicator Handbook.

Available at: http://ntnt.treasury.go.ke/wp-content/uploads/2020/11/MTP-III-IndicatorHandbook 2019.pdf

xxix The Republic of Kenya. (2019). Third National Reporting Indicator Handbook.

Available at: http://ntnt.treasury.go.ke/wp-content/uploads/2020/11/MTP-III-IndicatorHandbook 2019.pdf

xxx Gichuyia, L. N.; Madette, E. (2020). "OCHA: AFRICAN AVANT GARDE”. In Koolhaas. Countryside, A Report. Guggenheim - Taschen. ISBN 978-3-8365- 83312 .

xxxi Climate Adaptation Atlas. (2021). Available at: http://www.climate-atlas.ke/

xxxii Our World in Data. (2021). Kenya: $\mathrm{CO}_{2}$ Country Profile. Available at:

https://ourworldindata.org/co2/country/kenya

xxxiii Ministry of Environment And Forestry. (2018). National Climate Change Action

Plan (NCCAP) 2018-2022. Available at: https://www.kenyamarkets.org/wp-

content/uploads/2019/02/NCCAP-2018-2022-Online-.pdf

xxxiv Climate Links. (2021). Greenhouse Gas Emissions Factsheet: Kenya. Available at: https://www.climatelinks.org/resources/greenhouse-gas-emissions-factsheetkenya

xxxv United Nations Development Programme. (2017). Kenya Climate Smart

Agriculture Strategy - 2017-2026. Available at: https://www.adaptation-

undp.org/resources/plans-and-policies-relevance-naps-least-developed-countries-

Idcs/kenya-climate-smart

xxxvi Our World in Data. (2019). Kenya: $\mathrm{CO}_{2}$ Country Profile. Available at:

https://ourworldindata.org/co2/country/kenya

xxxvii Republic of Kenya. (2018). National Climate Change Action Plan 2018-2022.

Available at: https://www.Ise.ac.uk/Granthamlnstitute/wp-

content/uploads/2018/10/8737 vol3.pdf

xxxviii Salih, A., Baraibar, M., Mwangi, K., \& Artan, G. (2020). "Climate change and locust outbreak in East Africa” Nature Climate Change, 10(7), 584-585.

xxxix Food and Agriculture Organization of the United Nations. (2017). The future of food and agriculture. http://www.fao.org/3/i6583e/i6583e.pdf

${ }^{x l}$ Kenya Law Reform Commission. (2021). Chapter Eleven - Devolved Government. https://www.klrc.go.ke/index.php/constitution-of-kenya/138-chapter-eleven-devolvedgovernment

$\mathrm{xl}$

xli Gichuyia, L. (2010). Impact of buildings on climate change:A case of Nairobi's Upper Hill area;towards low energy Architecture. Undergraduate dissertation.

University of Nairobi.

xlii Our World in Data. (2019). Kenya: $\mathrm{CO}_{2}$ Country Profile. Available at:

https://ourworldindata.org/co2/country/kenya 
xliii Government of Kenya. (2010). National Climate Change Response Strategy.

http://www.environment.go.ke/wp-

content/documents/complete\%20nccrs\%20executive\%20brief.pdf

xliv Muhati, G. L., Olago, D., \& Olaka, L. (2018). Past and projected rainfall and temperature trends in a sub-humid Montane Forest in Northern Kenya based on the CMIP5 model ensemble. Global Ecology and Conservation, 16, e00469.

xlv Gichuyia, L. N. (2017), "Indoor Overheating Risk: A Framework For Temporal Building Adaptation Decision-Making". Doctoral dissertation submitted in partial fulfilment

of the requirements for a PhD in Architecture at the University of Cambridge.

https://doi.org/10.17863/CAM.17146

xlvi Kilavi, M., MacLeod, D., Ambani, M., Robbins, J., Dankers, R., Graham, R., ... \&

Todd, M. C. (2018). "Extreme rainfall and flooding over central Kenya including

Nairobi city during the long-rains season 2018: Causes, predictability, and potential for early warning and actions". Atmosphere, 9(12), 472.

xlvii The Conversation. (2021). What the budget holds for the agriculture sector in Kenya. https://theconversation.com/what-the-budget-holds-for-the-agriculture-sectorin-kenya-162531

xlviii Floodlist. (2021). Kenya - 40,000 Displaced by Recent Floods, Says Red Cross. http://floodlist.com/africa/kenya-floods-update-may-2021

xlix World Bank. 2021. Kenya Country Profile. [online] Available at:

$<$ https://climateknowledgeportal.worldbank.org/sites/default/files/2021-05/15724-

WB_Kenya\%20Country\%20Profile-WEB.pdf> [Accessed 21 October 2021].

I Government of Kenya. (2010). Kenya - National Climate Change Response Strategy. http://www.environment.go.ke/wpcontent/documents/complete\%20nccrs\%20 executive\%20brief.pdf

li World Bank Climate Change Knowledge Portal. 2021. World Bank Climate Change Knowledge Portal. [online] Available at:

$<$ https://climateknowledgeportal.worldbank.org/country/kenya/climate-data-

historical> [Accessed 21 October 2021].

lii Intergovernmental Panel on Climate Change. 2021. Regional Fact Sheet - Africa. [online] Available at:

<https://www.ipcc.ch/report/ar6/wg1/downloads/factsheets/IPCC_AR6_WGI_Region al_Fact_Sheet_Africa.pdf> [Accessed 21 October 2021].

liii https://naibuzz.com/mombasa-will-sink-next-20-years/

liv Awuor, B., Orindi, V. and Ochieng Adwera, O. (2008). Climate change and coastal cities: case of Mombasa, Kenya. Environment and Urbanization,20(1), 231-242.

lv Ranasinghe, R., A. C. Ruane, R. Vautard, N. Arnell, E. Coppola, F. A. Cruz, S. Dessai, A. S. Islam, M. Rahimi, D. Ruiz Carrascal, J. Sillmann, M. B. Sylla, C. Tebaldi, W. Wang, R. Zaaboul, 2021, Climate Change Information for Regional Impact and for Risk Assessment. In: Climate Change 2021: The PhysicalScience Basis. Contribution of Working Group I to the Sixth Assessment Report of the 
Intergovernmental Panel on Climate Change [Masson-Delmotte, V., P. Zhai, A. Pirani, S. L. Connors, C. Péan, S. Berger, N. Caud, Y. Chen, L. Goldfarb, M. I. Gomis, M. Huang, K. Leitzell, E. Lonnoy, J. B. R. Matthews, T. K. Maycock, T. Waterfield, O. Yelekçi, R. Yu and B. Zhou (eds.)]. Cambridge University Press

Ivi Klepeis, E., Nelson, C., Ott, R., Robinson, P., Tsang, M., Switzer, P., ... \& Engelmann, H. (2001). The National Human Activity Pattern Survey (NHAPS): a resource for assessing exposure to environmental pollutants. Journal of Exposure Science \& Environmental Epidemiology, 11(3), 231-252. Ivi

Ivii Gichuyia, L. N. (2017), "Indoor Overheating Risk: A Framework For Temporal Building Adaptation Decision-Making". Doctoral dissertation submitted in partial fulfilment of the requirements for a PhD in Architecture at the University of Cambridge. https://doi.org/10.17863/CAM.17146

Iviii Mwangi, H. Julich, S. Patil, S. McDonald, M. Feger, K-H. (2016). "Relative contribution of land use change and climate variability on discharge of upper Mara River, Kenya" Journal of Hydrology: Regional Studies 5 (0):244-260.

lix Mulwa, F., Li, Z., \& Fangninou, F. F. (2021). Water Scarcity in Kenya: Current Status, Challenges and Future Solutions. Open Access Library Journal, 8(1), 1-15.

Ix Kebede, S., Nicholls, J., Hanson, S., \& Mokrech, M. (2012). Impacts of climate change and sea-level rise: a preliminary case study of Mombasa, Kenya. Journal of Coastal Research, 28(1A), 8-19.

Ixi Kebede, S., Nicholls, J., Hanson, S., \& Mokrech, M. (2012). Impacts of climate change and sea-level rise: a preliminary case study of Mombasa, Kenya. Journal of Coastal Research, 28(1A), 8-19.

Ixii Dzoga, M., Simatele, D., \& Munga, C. (2018). Assessment of ecological vulnerability to climate variability on coastal fishing communities: A study of Ungwana Bay and Lower Tana Estuary, Kenya. Ocean \& Coastal Management, 163, 437-444.

Ixiii https://www.mdpi.com/2072-4292/12/9/1390

Ixiv Okaka, F and Odhiambo, B. (2019). Health vulnerability to flood-induced risks of households in flood-prone informal settlements in the Coastal City of Mombasa, Kenya. Natural Hazards. 99, 1007-1029

IxvIPCC. "Impacts of $1.5^{\circ} \mathrm{C}$ of Global Warming on Natural and Human Systems." Available at: https://www.ipcc.ch/sr15/chapter/chapter-3/

Ixvi Njiru B.N. (2012) Climate Change, Resource Competition, and Conflict amongst Pastoral Communities in Kenya. In: Scheffran J., Brzoska M., Brauch H., Link P., Schilling J. (eds) Climate Change, Human Security and Violent Conflict. Hexagon Series on Human and Environmental Security and Peace, vol 8. Springer, Berlin, Heidelberg. 
IxviiJ.H. Tuqa, P. Funston, C. Musyoki, G.O. Ojwang, N.N. Gichuki, H. Bauer, W. Tamis, S. Dolrenry, M. Van't Zelfde, G.R. de Snoo, H.H. de longh. (2014) Impact of severe climate variability on lion home range and movement patterns in the Amboseli ecosystem, Kenya. Global Ecology and Conservation 2: 1-10.

Ixviii Freeman, L. (2017). "Environmental Change, Migration, and Conflict in Africa: A Critical Examination of the Interconnections." The Journal of Environment \& Development, 26(4), 351-374

lxix Ranasinghe, R., A. C. Ruane, R. Vautard, N. Arnell, E. Coppola, F. A. Cruz, S. Dessai, A. S. Islam, M. Rahimi, D. Ruiz Carrascal, J. Sillmann, M. B. Sylla, C. Tebaldi, W. Wang, R. Zaaboul, 2021, Climate Change Information for Regional Impact and for Risk Assessment. In: Climate Change 2021: The PhysicalScience Basis. Contribution of Working Group I to the Sixth Assessment Report of the Intergovernmental Panel on Climate Change [Masson-Delmotte, V., P. Zhai, A. Pirani, S. L. Connors, C. Péan, S. Berger, N. Caud, Y. Chen, L. Goldfarb, M. I. Gomis, M. Huang, K. Leitzell, E. Lonnoy, J. B. R. Matthews, T. K. Maycock, T. Waterfield, O. Yelekçi, R. Yu and B. Zhou (eds.)]. Cambridge University Press

Ixx http://jgesnet.com/vol-4-no-2-december-2016-abstract-1-jges or https://www.omicsonline.org/peer-reviewed/a-review-of-the-future-of-tourism-incoastal-kenya-the-challenges-and-opportunities-posed-by-climate-change29421.html

IxxiMose, R. (2017). "Vulnerability and impact assessment of climate change on East African wildlife tourism." In: Heshmati, An Economic Transformation for Poverty Reduction in Africa. London: Routledge.

Ixxii FAO. (2015). "Country Profile: Kenya." Available at:

http://www.fao.org/3/i9762en/l9762EN.pdf

Ixxiii Uhe, P. Philip, S. Kew, S. Shah, K. Kimutai, J. Mwangi, E. et al. (2017).

"Attributing drivers of the 2016 Kenyan drought." International Journal of Climatology 38 (S1).

lxxiv Ranasinghe, R., A. C. Ruane, R. Vautard, N. Arnell, E. Coppola, F. A. Cruz, S. Dessai, A. S. Islam, M. Rahimi, D. Ruiz Carrascal, J. Sillmann, M. B. Sylla, C. Tebaldi, W. Wang, R. Zaaboul, 2021, Climate Change Information for Regional Impact and for Risk Assessment. In: Climate Change 2021: The PhysicalScience Basis. Contribution of Working Group I to the Sixth Assessment Report of the Intergovernmental Panel on Climate Change [Masson-Delmotte, V., P. Zhai, A. Pirani, S. L. Connors, C. Péan, S. Berger, N. Caud, Y. Chen, L. Goldfarb, M. I. Gomis, M. Huang, K. Leitzell, E. Lonnoy, J. B. R. Matthews, T. K. Maycock, T. Waterfield, O. Yelekçi, R. Yu and B. Zhou (eds.)]. Cambridge University Press

Ixxv International Trade Forum. (2010). "Climate Change and Coffee." Available at: https://www.tradeforum.org/Climate-Change-and-the-Coffee-Industry/

Ixxvi https://iopscience.iop.org/article/10.1088/1748-9326/ab70be/meta 
Ixxvii Awuor, C. Orindi, V. Adwera, A. (2008). "Climate change and coastal cities: the case of Mombasa, Kenya." Environment and Urbanization 20 (1)

Ixxviii African Development Bank Group. (2021). "Kenya's path towards sustainable electricity for all." Available at: https://blogs.afdb.org/fr/climate-changeafrica/kenya\%E2\%80\%99s-path-towards-sustainable-electricity-all-312

IxxixWRI. (2017). "No Water, No Power.” Available at: https://www.wri.org/insights/nowater-no-power

Ixxx KenGen. (n.d.) "Homepage." Available at:

https://kengen.co.ke/index.php?page=business\&subpage=wind\&id=131

Ixxxi Ndebu, P. (2015). "Air Conditioning Companies in Kenya." Available at:

http://www.kenyahomesguide.com/896/air-conditioning-companies/

Ixxxii IFAD. (2020). Kenya Livestock Commercialization Project Design Report.

Available at: Main report and annexeshttps://www.ifad.org/en/-/document/kenya2000002339-kelcop-project-design-report-july-2020

Ixxxiii Green Climate Fund. (2019). "Towards Ending Drought Emergencies: Ecosystem Based Adaptation in Kenya's Arid and Semi- Arid Rangelands." Available at:

https://www.greenclimate.fund/sites/default/files/document/funding-proposal-fp113iucn-kenya.pdf

Ixxxiv Sustainable Development Report. (n.d.). "Dashboard." Available at: https://dashboards.sdgindex.org/rankings

IxxxvGovernment of Kenya. (2010). "National Climate Change Response Strategy." Available at: http://www.environment.go.ke/wp-

content/documents/complete\%20nccrs\%20executive\%20brief.pdf

Ixxxvi The World Bank. (2019). 'Program Information Document.' (PID). Available at: https://documents1.worldbank.org/curated/en/762721583745126806/pdf/ConceptStage-Program-Information-Document-PID-Financing-Locally-Led-Climate-ActionProgram-P173065.pdf

IxxxviiThe Government of Kenya. (n.d.) Kenya Green Bond Guidelines Background Document (draft 2). Available at: https://www.nse.co.ke/products-services/debtsecurities/the-green-bond.html?download=10262\%3Akenya-green-bondprogramme-guidelines

Ixxxviii Egerton University. (2015). "Uptake of Crop Insurance in Kenya in the Face of Climate Change: Policy Brief no. 15." Available at:

https://www.tegemeo.org/images/ tegemeo institute/downloads/publications/policy briefs/policy brief15.pdf

Ixxxix Nkatha, L. (2017). "Indoor overheating risk: a framework for temporal building adaptation decision-making." Available at:

https://ethos.bl.uk/OrderDetails.do?uin=uk.bl.ethos.744389 
xc Gichuyia, N. Madette, E. (2020), "OCHA: AFRI-CAN AVANT GARDE”. In

Koolhaas. Countryside, A Report. Guggenheim - Taschen. ISBN 978-3-8365- 83312.

xci Gichuyia, N. Madette, E. (2020), “OCHA: AFRI-CAN AVANT GARDE”. In Koolhaas. Countryside, A Report. Guggenheim - Taschen. ISBN 978-3-8365- 83312.

xcii ICRAF. (2006). "Status of carbon sequestration projects in Africa:

Potential benefits and challenges to scaling up." Available at:

http://apps.worldagroforestry.org/downloads/Publications/PDFS/wp14441.pdf

xciii UNEP RISO Centre. (n.d.). "Carbon Markets and Africa: A Quick Fact Sheet for Journalists." Available at:

https://www.afdb.org/fileadmin/uploads/afdb/Documents/Generic-

Documents/Carbon\%20Market\%20Quick\%20Facts\%20\%20ACF\%202012.pdf

xciv National Construction Authority. (2020). National Building Regulations 2020.

Available at: https://nca.go.ke/component/k2/item/16-national-building-regulations-

2020

xcv The Kenyan Gazette. (2020). 17 ${ }^{\text {th }}$ April, 2020. Available at:

https://www.africalegalnetwork.com/covidhub/assets/downloads/press-

releases/kenya-gazette-apr17.pdf

xcviNjoroge, P. "African vision for sustainable finance." The Star. Available at:

https://www.the-star.co.ke/opinion/columnists/2020-01-15-african-vision-for-

sustainable-finance/

xcviiGichuyia, N., Omenya, A., Ngobi, B., Omanwa, P., \& Gathoni, M. (2021). COVID19 Management In Kenya's Informal Settlements _ A Blueprint For Pandemic Response And Recovery In Kenya's Informal Settlements. For the Foreign, Commonwealth and Development Office. London.

xcviii Government of Kenya, County Government ToolKit. (2007). Kenya Vision 2030:

Popular Vision. Availabe at: https://countytoolkit.devolution.go.ke/resource/kenya-

vision-2030-popular-version-government-kenya-gok-2007

${ }^{x c i x}$ County Government of Meru. (2019). Meru Vision 2040: A Prosperous, United and Happy Society. Available at:

https://meru.go.ke/assets/file/MERU\%20VISION\%202040-

POPULAR\%20VERSION.pdf

c Green Policy Platform. (2012). "Greening the Economy with Agriculture. Available at: https://www.greengrowthknowledge.org/research/greening-economy-agriculture

ci Transparency International Kenya. (2018). "A Human Rights-Based Approach to Climate Risk: The Case of Kenya. Available at: https://tikenya.org/wp-

content/uploads/2019/05/Climate-Risk-Insurance-Report.pdf

cii Ministry of Transport, Infrastructure, House and Urban Development, The Government of Kenya. "FAQs." Available at: https://housingandurban.go.ke/nationalhygiene-programme-kazi-mtaani/ 
ciii State Department of Youth Affairs, The Government of Kenya. "Training of Mtaani Beneficiaries." Available at: http://youth.go.ke/kazi-mtaani/

civ Rhino Ark Charitable Trust. (2018). Newsletter Issue 53. Available at: http://rhinoark.org/wp-content/uploads/2018/12/ARKive-Nov-2018Final.pdf

cv Viagroforestry. (n.d.) Home page. Available at: https://viagroforestry.org/projects/kacp/

cvilTC. (2014). Mitigating Climate Change in the Tea Sector. Available at: https://www.intracen.org/uploadedFiles/intracenorg/Content/Publications/Climate\%2 0Change\%20Tea-\%20Final\%20Manual Low\%20Res.pdf

cvii Green Climate Fund. (2020). "Climate Action During the Pandemic." Available at: https://www.greenclimate.fund/annual-results-report-2020

cviii Loki, D. (2009). Passive \& low energy building design in Nairobi: Building Design Strategies for Thermal comfort, Day-lighting \& Natural Ventilation in Nairobi's Tropical Upland Climate. Undergraduate dissertation. University of Nairobi.

cix Mogo E., Oni T. (2020) Human Resources for Global Health. In: Haring R., Kickbusch I., Ganten D., Moeti M. (eds) Handbook of Global Health. Springer, Cham. https://doi.org/10.1007/978-3-030-05325-3 106-1.

cx Mogo, E. Lerno, A. Abdeta, C. Olufemi,O. (2019). "Mounting an effective socioecological response to non-communicable diseases in Africa's cities." Cities \& Health: https://doi.org/10.1080/23748834.2019.1688911

cxi ACT Alliance. (2020). "Climate Risk Insurance and Risk Financing in the Context of Climate Justice - A Manual for Development and Humanitarian Aid Practitioners." Available at: https://reliefweb.int/report/world/climate-risk-insuranceand-risk-financing-context-climate-justice-manual-development

cxii See "Kenya Coastal Development project (KCDP). Locals on Wasini Island have since grown more than 3,000 corals" There is potential to build more. See alsoMcclanahan, T. Obura, D. (1995) "Status of Kenyan Coral Reefs" Coastal Management, 23(1): 57-76

cxiii Mugidde, R. Hecky, R. Ndawula, L. (2005). "Eutrophication of Lake Victoria, Uganda." Available at:

https://www.mwe.go.ug/sites/default/files/library/Chapter\%208\%20Eutrophication.pdf

cxiv Reed, D. Dugan, H. Flannery, A. Desai, A. (2018). "Carbon sink and source dynamics of a eutrophic deep lake using multiple flux observations over multiple years." ASLO 3, (0): 285-292

cxv Njeru, P. (2008). "Investigating Thermal Comfort in Urban Transitional Spaces." MPhil dissertation. University of Cambridge. 
cxviProject Drawdown. (2020). "Farming our way out of the climate crisis." Available at:

https://drawdown.org/sites/default/files/pdfs/DrawdownPrimer FoodAgLandUse Dec 2020 01c.pdf

cxviiUN CC: Learn. (2010). "Greenhouse Gas Emissions from the Dairy Sector: A Life Cycle Assessment." Available at:

https://www.uncclearn.org/resources/library/greenhouse-gas-emissions-from-the-

dairy-sector-a-life-cycle-assessment

cxviii Koolhaas, R. (2020). Countryside: A Report. Available at:

https://onlinelibrary.wiley.com/doi/abs/10.1111/1468-2427.12960?af=R

cxix COP 23. (2017). Mitigation, Adaptation and Resilience: The Three Pillars of the

Response to Global Warming. Available at: https://cop23.com.fj/mitigation-

adaptation-resilience/

cxxKoolhaas, R. (2020). Countryside: A Report. Available at:

https://onlinelibrary.wiley.com/doi/abs/10.1111/1468-2427.12960?af=R

cxxi COEACP. (n.d.) "Review of food miles, carbon, and African horticulture:

environmental and developmental issues." Available at:

http://www.gci.org.uk/Documents/PIP.pdf

cxxiiThe World Bank. (2017). "Project Appraisal Document on Proposed Credit in the Amount of SDR184.7 to the Republic of Kenya. Available at:

https://documents1.worldbank.org/curated/en/440241486868444705/pdf/Kenya-

PAD-01182017.pdf

cxxiiifFAO. (n.d.). "Developing sustainable food systems and value chains for climatesmart agriculture." Available at:http://www.fao.org/climate-smart-agriculturesourcebook/production-resources/module-b10-value-chains/chapter-b10-1/en/

cxxivFAO. (n.d.) "Mitigation of Climate Change in Agriculture (MICCA) Programme." Available at:

http://www.fao.org/in-action/micca/on-the-ground/africa/kenya/en/

cxxvFAO. (n.d.) "Climate Smart Agriculture. Available at: http://www.fao.org/climatesmart-agriculture/en/

cxxvi Wilkes, A. Wassie, S. Odhong', C. Fraval, S. van Dijk, S. (2020).

Variation in the carbon footprint of milk production on smallholder dairy farms in central Kenya,

Journal of Cleaner Production

265: 2020

cxxvii FAO. (2017). "Options for low-emission development

in the Kenya dairy sector: Reducing enteric methane for food security and

livelihoods." Available at: http://www.fao.org/3/i7669e/i7669e.pdf

cxxviii IPCC. (n.d.). "Climate Change Adaptation and Mitigation 
in the Kenyan Coffee Sector." Available at:

https://www.ipcc.ch/apps/njlite/ar5wg2/njlite download2.php?id=8264

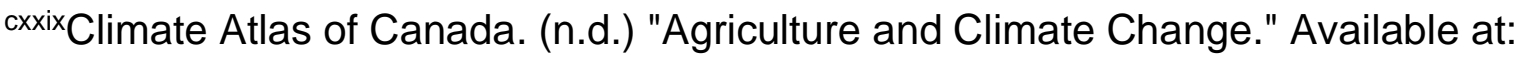
https://climateatlas.ca/agriculture-and-climate-change

cxxx GreenInsect. (n.d.) "Technical brief \#1: Insects as food and feed in Kenya - past, current and future perspectives." Available at:

https://greeinsect.ku.dk/news/technical-brief/GREEiNSECT-BRIEF.pdf

cxxxi Nathaniel, M. Hideyuki, D (2019). 'Global Simulation of Insect Meat Production Under Climate Change.' Frontiers in Sustainable Food Systems 3 (0): 91

cxxxii Welfle, A. Chingaira, S. Kassenov, A. (2020). "Decarbonising Kenya's domestic \& industry Sectors through bioenergy: An assessment of biomass resource potential \& GHG performances."

Biomass and Bioenergy

$142(0): 105757$

cxxxiii Welfle, A. Chingaira, S. Kassenov, A. (2020). "Decarbonising Kenya's domestic $\&$ industry Sectors through bioenergy: An assessment of biomass resource potential \& GHG performances."

Biomass and Bioenergy

$142(0): 105757$

cxxxiv Government of Kenya. (2010). National Climate Change Response Strategy April Executive Brief. Available at: https://cdkn.org/wp-

content/uploads/2011/12/National Climate Change Response Strategy Executive Brief.pdf

cxxxv SocialProtection.org. (n.d.). Njaa Marufuku Kenya (NMK)—School Feeding Programme. Available at: https://socialprotection.org/discover/programmes/niaamarufuku-kenya-nmk-school-feeding-programme

cxxxvi The Green Belt Movement. Retrieved 21 October 2021, from

http://www.greenbeltmovement.org

cxxxvii Innovative approaches to accelerating and scaling up climate technology implementation for mitigation and adaptation. (2021). Retrieved 21 October 2021, from

https://unfccc.int/ttclear/misc_StaticFiles/gnwoerk_static/innovative_approaches/07a 2f73969c945928ffa1ec74285f356/235654758e1343f788b1f1132bb109b8.pdf

cxxxviii Chermuliti, J. (2015). An assessment of the feasibility of carbon trading afforestation contracts in trans Mara sub-county, Kenya. Available at:

http://erepository.uonbi.ac.ke/handle/11295/90106

cxxxix Holkenborg, M. (2020). "Towards climate resilient smallholder horticulture in Kiambu and Kajiado counties, Kenya." Available at: https://www.3r-kenya.org/wp-content/uploads/2020/06/MSc-Thesis-Marjel-kleinHolkenborg.pdf 
cxlSafaricom. (2020. Resilience through transition: 2020 sustainable report. Available at:

https://www.safaricom.co.ke/images/Downloads/Resources Downloads/2020 Safari com Sustainable Business Report Final.pdf

cxli ILRI. (2020). "Youth opportunity spaces in low-emission dairy development in Kenya: Research findings and policy recommendations. Available at:

https://www.ilri.org/publications/youth-opportunity-spaces-low-emission-dairydevelopment-kenya-research-findings-andhttp://www.gci.org.uk/Documents/PIP.pdf 